\title{
Organoselenium Chemistry. Conversion of Ketones to Enones by Selenoxide Syn Elimination
}

\author{
Hans J. Reich,* James M. Renga, and Ieva L. Reich \\ Contribution from the Department of Chemistry, University of Wisconsin, \\ Madison, Wisconsin 53706. Received February 28, 1975
}

\begin{abstract}
The scope and limitation of the transformation of ketones to enones by selenenylation followed by selenoxide elimination have been examined. Several procedures for the preparation of $\alpha$-phenylseleno ketones have been developed. The most useful are direct selenenylation of ketone enolates using $\mathrm{PhSeBr}$ and the reaction of enol acetates with electrophilic selenium species such as benzeneselenenyl trifluoroacetate. Several oxidants (ozone, hydrogen peroxide, sodium metaperiodate) and reaction conditions are described to allow optimization of the yield obtained in the transformation of $\alpha$-phenylseleno ketones to enones. The reaction is quite general for acyclic carbonyl compounds and for tertiary selenides. Difficulties in achieving high yields may be anticipated when very strained double bonds are introduced, when the $\alpha$-phenylseleno ketone is cyclic and has an $\alpha$-hydrogen, or when the product is extremely reactive. Qualitative mechanistic studies have revealed two types of side reactions: (1) Pummerer-like transformations to give $\alpha$-diketones and (2) reactions between the enolate or enol of $\alpha$-phenylselenino ketones and selenenylating species formed during the disproportionation of benzeneselenenic acid. Reaction conditions which minimize these side reactions have been developed. The utility of benzeneseleninyl chloride as a seleninylating agent has been explored. One pot transformations of ketones to enones using this reagent can be achieved in satisfactory yield, but the procedure is prone to side reactions because of the sensitivity of the selenoxide function.
\end{abstract}

The many synthetic transformations originating from $\alpha, \beta$-unsaturated carbonyl compounds have made their preparation a long standing important synthetic problem. The most straightforward method is the dehydrogenation of carbonyl compounds. There are a number of methods for performing this conversion, ${ }^{1,2}$ the most important of which is the $\alpha$-bromination-dehydrobromination method. ${ }^{1}$ Orientational control is difficult to achieve in direct bromination of ketones, but Stotter and Hill ${ }^{\text {ld }}$ have recently shown that bromination of cyclohexanone enolates can be carried out in high yield, and also that dehydrobromination can be performed without loss of regiospecificity. Isomerization of $\alpha$ bromo ketones under conditions of the debrominations has been frequently reported, ${ }^{\text {le }}$ however, particularly for bromides of $\beta$-dicarbonyl compounds. ${ }^{1 \mathrm{f}, \mathrm{g}}$ The vigorous reaction conditions (frequently temperatures in excess of $120^{\circ}$ ) also severely limit this method because of the sensitivity of many enones.

Direct dehydrogenations can be performed by a number of reagents, including selenium dioxide, ${ }^{2 a, b}$ dichlorodicyanoquinone, ${ }^{2 \mathrm{c}}$ periodic acid, ${ }^{2 \mathrm{~d}}$ oxygen in the presence of transition metal catalysts, ${ }^{2 e}$ and pyridine $N$-oxide-acetic anhydride. ${ }^{2 f}$ The first two methods have been studied in great detail, and some excellent procedures have been developed, but yields vary greatly, and effective control of regioselectivity is frequently a problem.

The discovery by Jones, Mundy, and Whitehouse ${ }^{3}$ that selenoxides undergo clean syn elimination to form olefins at or below room temperature suggested that this reaction may offer a solution to the problem discussed above. We report here full details of our work ${ }^{4 a-c}$ on the conversion of ketones to enones using the selenoxide elimination (eq 1).

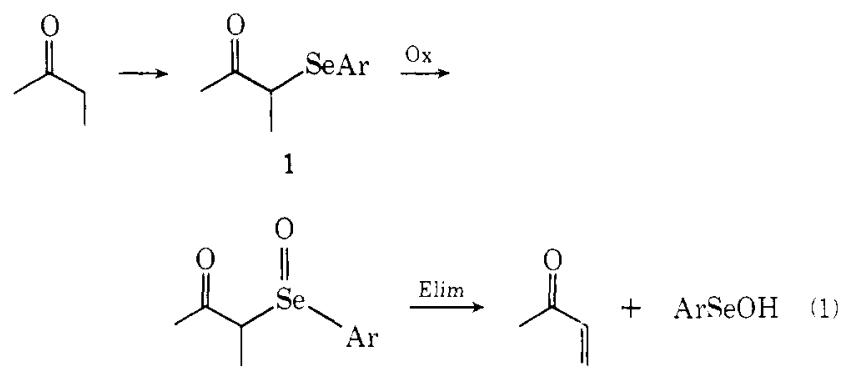

Sharpless and Lauer first used selenoxide eliminations synthetically in the conversion of epoxides to allyl alcohols. ${ }^{5 b, d}$ Several groups ${ }^{4-8}$ have explored the reaction for the dehydrogenation of ketones, ${ }^{4 a, b, 5 c, 6 a}$ esters, ${ }^{4 a, 5 c}$ lactones, ${ }^{5 c, 7 a}$ and nitriles. ${ }^{8}$ Selenium stabilized anions ${ }^{9}$ have been used for formation of new carbon-carbon bonds, with subsequent selenoxide elimination to give $\alpha, \beta$-unsaturated esters, ${ }^{5 c, 10 a}$ olefins, ${ }^{4 d, 11}$ allyl alcohols, ${ }^{4 d e, 9 b c}$ and dienes. ${ }^{4 d}$ Sulfoxide eliminations have also been explored for the introduction of unsaturation. $4 \mathrm{f}, 7 \mathrm{c}, 10$

Preparation of $\alpha$-Phenylseleno Ketones. ${ }^{12}$ Literature methods for the preparation of the required $\alpha$-arylseleno carbonyl compounds (1) were not suitable for the problem at hand. $\alpha$-Arylseleno carboxylic esters have been prepared by nucleophilic displacements of $\alpha$-halo esters by phenylselenolate anion..$^{5 c, 13} \alpha$-Bromo ketones also undergo displacements, provided the proper mode of addition (PhSeM to bromo ketone) is used under aprotic conditions, otherwise dehalogenation occurs. ${ }^{14}$ This method may be useful in special cases.

Rheinboldt and Perrier ${ }^{15}$ found that $o$-nitrobenzeneselenenyl thiocyanate (ArSeSCN) reacts with acetone to form $\alpha$-arylseleno acetone. The reagent is not readily available, however, and the reaction has not been shown to be general. Although selenenyl bromides often brominate ketones, the chlorides behave as selenenylating agents. ${ }^{5 c, 16}$ Sharpless, Lauer, and Teranishi discovered that benzeneselenenyl chloride converts aldehydes and ketones to their $\alpha$-phenylseleno derivatives, and this represents an important route to compounds which are not accessible by other methods. ${ }^{5 c}$

We have developed three routes to $\alpha$-phenylseleno ketones, as shown for 2 in Scheme I. A number of specific examples are summarized in Table I. The most widely useful method is the reaction of ketone (and ester) enolates with benzeneselenenyl bromide or chloride ( $\mathrm{PhSeBr}, \mathrm{PhSeCl})$. These reagents are prepared by cleavage of diphenyl diselenide $(\mathrm{PhSeSePh})$ with bromine and chlorine (or sulfuryl chloride), respectively. Diphenyl diselenide does not react with lithium enolates of ketones but does react with ester enolates $^{5 c, 7}$ and more reactive carbanions. ${ }^{8,12}$

The failure of ketone enolates to react with diphenyl diselenide is apparently the result of an unfavorable equilibrium rather than of a kinetic barrier. Treatment of 2 with $\mathrm{PhSeLi}$ at $-78^{\circ}$ results in the rapid and almost quantitative 
Scheme I
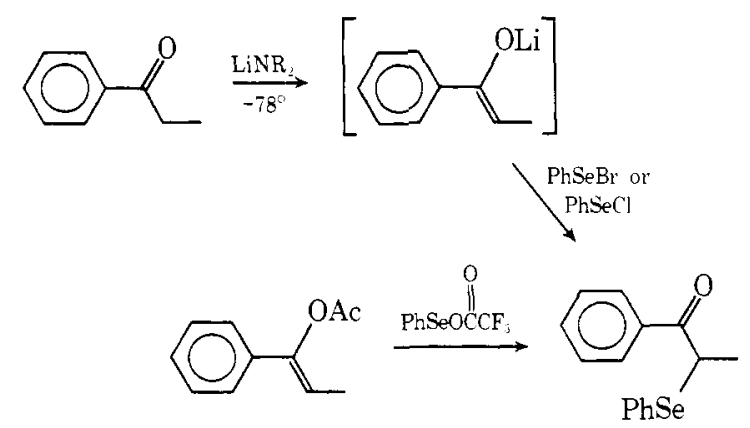

2

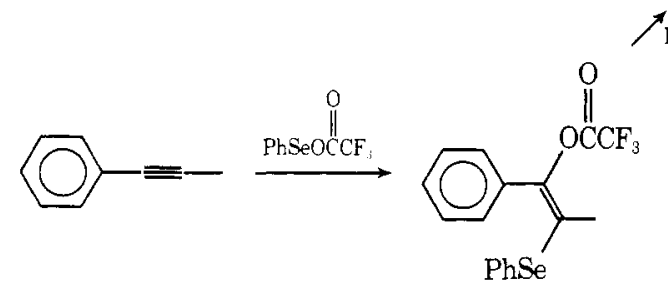

formation of diphenyl diselenide and, presumably, the enolate. ${ }^{17}$

$$
\overbrace{\mathrm{SePh}}^{\mathrm{O}}+\mathrm{PhSeLi} \stackrel{-78^{\circ}}{\longrightarrow}
$$

The selenenylation of ketones via the enolate is limited primarily by the availability of the enolate. Yields are frequently almost quantitative. The major by-product we have detected is starting ketone, usually present to the extent of $2-10 \%$ in the product. Where this is objectionable, the more volatile starting material can be removed by distillation or sublimation; or the selenides, which are frequently crystalline, can be purified by crystallization. In a few systems, we have tentatively identified traces of bis-selenenylated materials. Since reaction of enolate with selenenyl halide is very rapid at $-78^{\circ}$, enolate equilibration is not normally a problem (runs $11,13,16$, and 25). Brattesani and Heathcock ${ }^{8}$ have recently reported that proton transfer during selenenylation of nitrile anions is unavoidable. Nitrile anions, perhaps because of their immunity to steric inhibition of resonance, frequently undergo disubstitution in competition with, or in preference to, monosubstitution. 18

For most of the examples shown, we have prepared enolates by deprotonation of ketones using lithium diisopropylamide (LDA), but enolates prepared by cleavage of enol acetates with methyllithium (run 18), by conjugate addition of organocuprates, or by metalation of ketones with potassium hydride, ${ }^{19}$ can also be converted to $\alpha$-phenylseleno ketones.

It is important to use a quantity of selenenylating agent equal to or slightly in excess of the total strong base present since organocopper reagents, lithium amides, alkoxides, etc. may react with $\mathrm{PhSeBr}$. The choice between $\mathrm{PhSeBr}$ and $\mathrm{PhSeCl}$ is dictated mainly by availability of the reagents; $\mathrm{PhSeBr}$ can conveniently be prepared in solution as needed, and we have used this method for most of the examples reported here. Care must be taken to avoid excess bromine and to ensure mixing of the solution during the reaction with $\mathrm{PhSeSePh}$ to prevent formation of $\mathrm{PhSeBr}_{3}$, which is a brominating agent toward enolates.

The selenenylation of copper enolates prepared by conjugate addition of organocuprates to enones is complicated by the formation of small amounts of $\alpha$-bromo and $\alpha$-iodo ketones when pure $\mathrm{PhSeBr}$ is used. ${ }^{4 b} \mathrm{We}$ have found that use of a mixture of $\mathrm{PhSeBr}$ and $\mathrm{PhSeSePh}$ solves this problem, although overall yields are not always high. A more satisfactory route may be to trap the enolate as the enol acetate with acetic anhydride. The purified enol acetate can then be converted to $\alpha$-phenylseleno ketone in high yield. ${ }^{4 c, 6 a}$ (Stotter and Hill ${ }^{1 d}$ reported difficulty in the bromination of copper enolates; they found that clean bromination could be achieved through the enol acetate.) Thus, formation of selenide 3 and easy transformation to 4 represent a net $\beta$-alkylation of the enone.

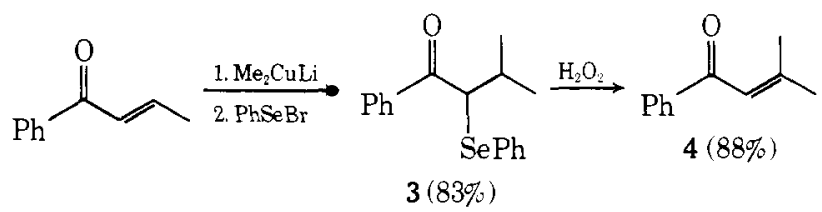

Even stabilized lithium and sodium enolates such as those formed from $\beta$-keto esters (runs $32-35$ ), $\beta$-diketones (runs 36-40), $\beta$-keto sulfoxides (run 41 ), $\beta$-keto selenoxides, ${ }^{4 b}$ and phosphonoacetates ${ }^{20}$ react cleanly and rapidly with $\mathrm{PhSeBr}$ and $\mathrm{PhSeCl}$.

Enol acetates can be cleanly converted to seleno ketones via the enolates (run 18) or by direct reaction with electrophilic selenium reagents. The reagent we have found most useful for this reaction is benzeneselenenyl trifluoroacetate ${ }^{4 \mathrm{c}, 6}\left(\mathrm{PhSeO}_{2} \mathrm{CCF}_{3}\right)$ which is prepared by treatment of $\mathrm{PhSeCl}$ or $\mathrm{PhSeBr}$ with silver trifluoroacetate. The only enol acetate we have encountered which does not react with $\mathrm{PhSeO}_{2} \mathrm{CCF}_{3}$ is 1-acetoxy-2-phenylcyclohexene (run 18). By using enol acetates formed under acid catalyzed conditions, ${ }^{21}$ it is often possible to achieve the preparation of $\alpha$ phenylseleno ketones regioisomeric with those prepared from the kinetic enolate. ${ }^{1 d}$ We have in this way prepared isomeric enones from 2-phenylcyclohexanone (runs 16-18) and 2-benzylcyclopentanone (runs 11-12).

The conversion of acetylenes to $\alpha$-phenylseleno ketones (Scheme I) has not been examined extensively as to generality and regioselectivity. ${ }^{4 c}$

The Oxidation Reaction. With adequate methods for the preparation of keto selenides available, we can turn to the question of the oxidation reaction. The majority of the results described in Table I were obtained using the following oxidation methods, which are discussed in more detail below:

A. $\mathrm{H}_{2} \mathrm{O}_{2}$ : one pot procedure. ${ }^{4 \mathrm{a}}$

B. $\mathrm{H}_{2} \mathrm{O}_{2}$ : two phase $\left(\mathrm{H}_{2} \mathrm{O}_{2}\right.$-dichloromethane) usually buffered with pyridine. ${ }^{4 b}$

C. $\mathrm{O}_{3}$ : Ozonization at $-78^{\circ}$ in dichloromethane followed by warm up.

D. $\mathrm{O}_{3}$ : Ozonization at $-78^{\circ}$ in dichloromethane followed by addition to refluxing carbon tetrachloride in the presence of diisopropylamine.

E. Selenoxide prepared directly by reaction of enolate with benzeneseleninyl chloride.

Since all keto selenoxides we have worked with undergo the fragmentation reaction at or below room temperature, the oxidation must either be performed at low temperature, or the product enone must not itself be readily oxidized by the oxidizing agent chosen. We have explored sodium metaperiodate, ${ }^{22 a}$ ozone, ${ }^{22 b}$ hydrogen peroxide, ${ }^{22 c}$ and to a lesser extent $m$-chloroperbenzoic acid ( $m$-CPBA) as oxidants. Because of its expense and the necessity of working in an aqueous methanolic medium, sodium metaperiodate is a reagent of last resort. Two selenides for which superior yields were obtained using this reagent are shown in runs 1 and 19 of Table I. 


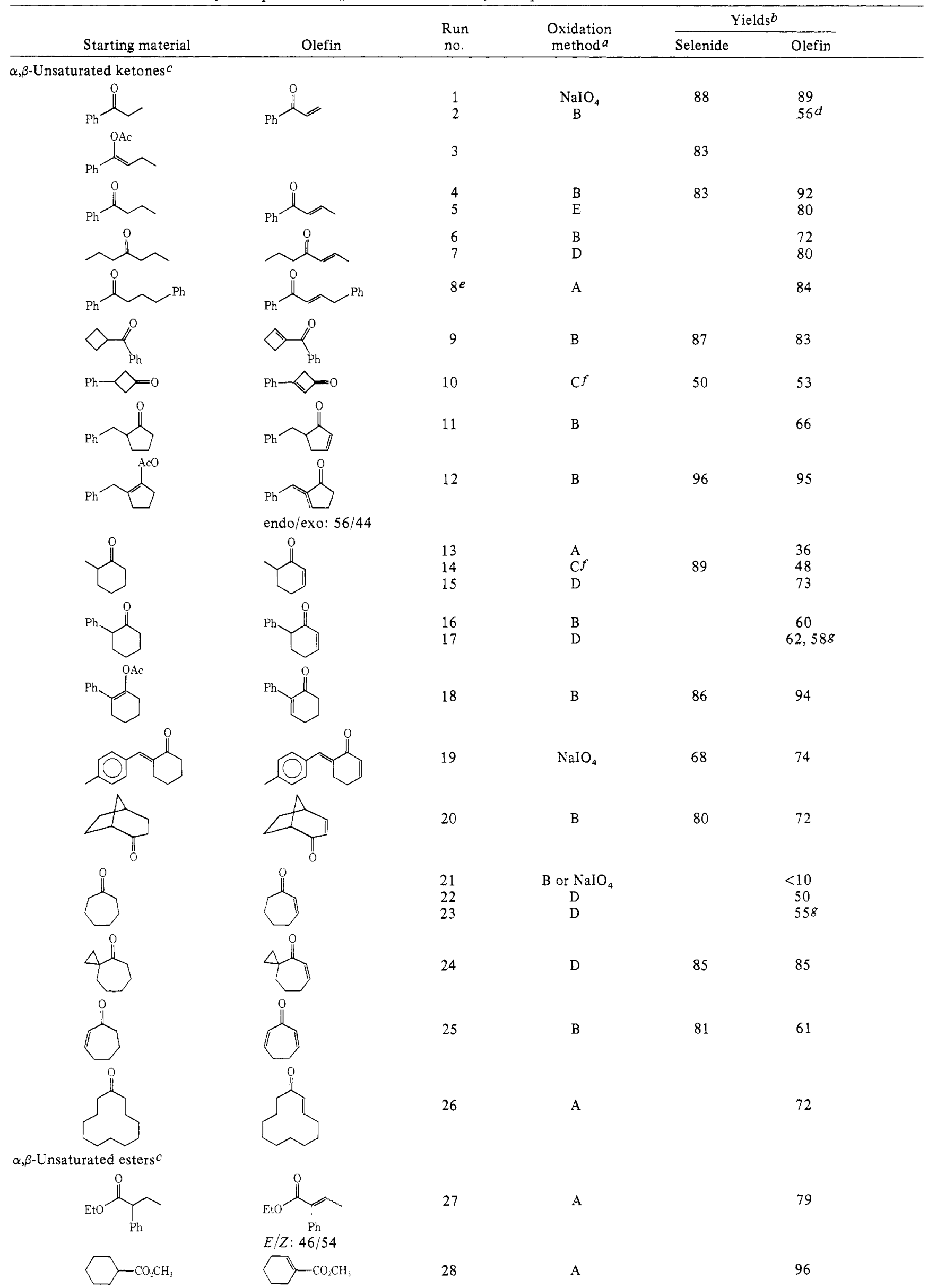




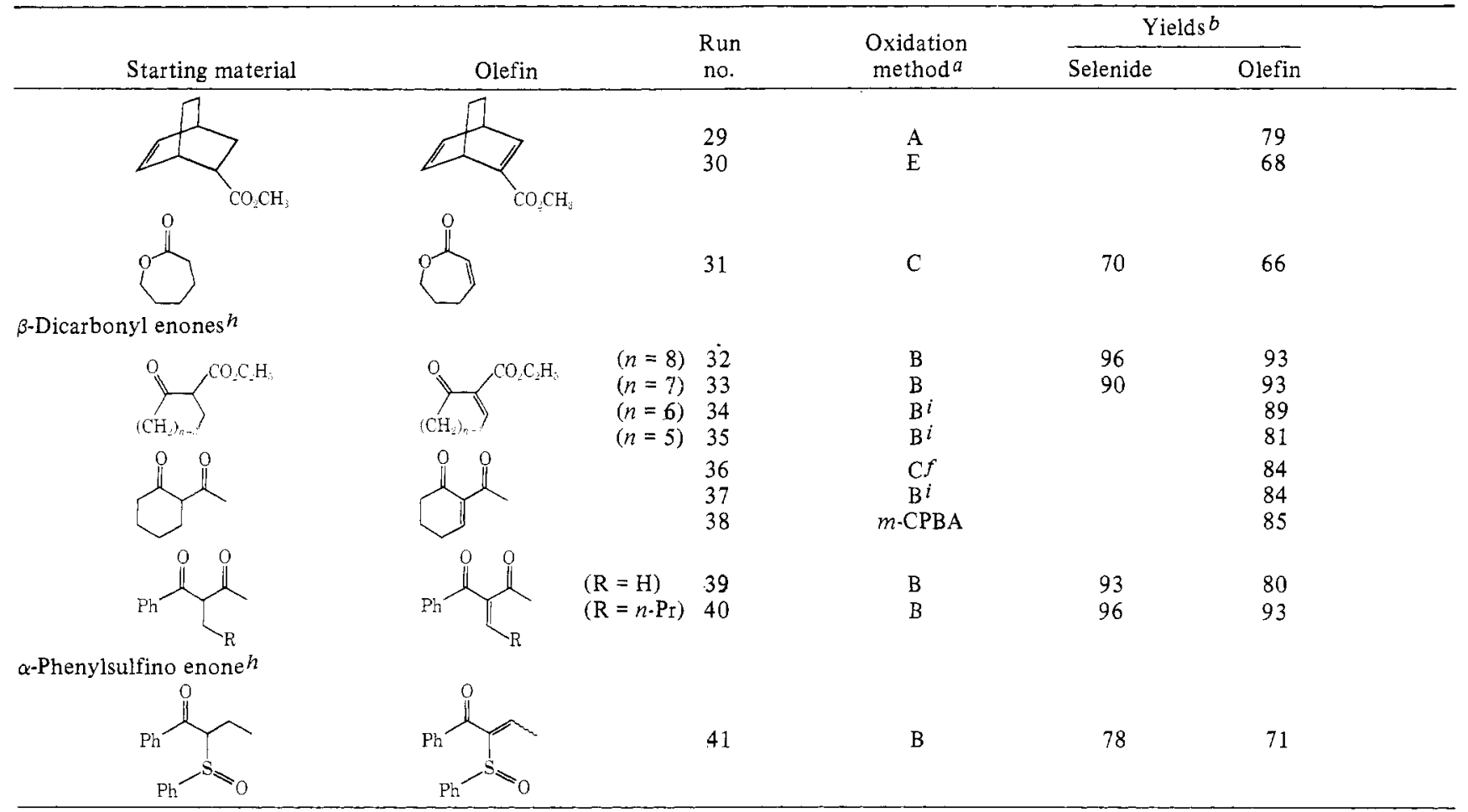

$a$ See text for a description of the oxidation procedures. $b$ Olefin yields are overall unless yields of selenide are given. $c$ Selenides were prepared from the lithium enolate, except for runs 3 and $12 . d_{\alpha}$-Diketone $(6 \%)$ was also formed. $e$ See ref 4 a for experimental details. $f$ Pyridine was added during selenoxide elimination. $g$ Diethylamine rather than diisopropylamine was used during selenoxide elimination (method $D$ ).

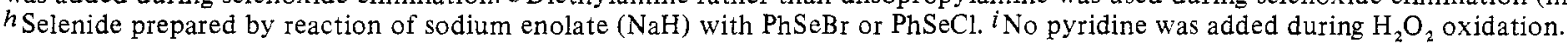

Ozonization of selenides $22 \mathrm{~b}$ at $-78^{\circ}$ stops cleanly at the selenoxide stage so that, in the absence of other readily ozonized functionalities or solvents (such as THF), one can simply add excess ozone. We have used ozonization when an aqueous work-up is undesirable because of substrate reactivity or water solubility (run 31 ), when the enone product is sensitive to excess hydrogen peroxide (as in runs 10, 36), when further transformations of the selenoxide are to be carried out, ${ }^{4 b, d}$ or when oxidation and elimination are best carried out in separate steps (method D). The enone can sometimes be distilled directly out of the ozonization mixture provided that the volatility of the $\mathrm{PhSeSePh}[\mathrm{bp}$ $\left.202-203^{\circ}(11 \mathrm{~mm})\right]$ formed is not near that of the product.

$m$-Chloroperbenzoic acid cleanly oxidizes selenides to selenoxides, usually at temperatures $\left(-30\right.$ to $\left.0^{\circ}\right)$ where elimination is slow. This oxidant can thus often be used in situations similar to those described above for ozone with the added advantage that selective oxidation of selenides or $\mathrm{Ph}_{2} \mathrm{Se}_{2}$ in the presence of double bonds can be more readily carried out. ${ }^{4 d}$

Hydrogen peroxide is the oxidant of choice under aqueous conditions. We have developed a one-pot procedure (method A) in which the oxidation is done directly without isolation of the selenide. It requires the least manipulation, and is ideal when contamination by small amounts of starting carbonyl compound is not objectionable, and when the elimination is uncomplicated by side reactions (see below). A second procedure (method B) is a two phase method (dichloromethane-aqueous hydrogen peroxide) which is convenient, requires only a small excess of hydrogen peroxide, is easy to control for larger scale oxidations, and gives superior yields to other methods using hydrogen peroxide that we have examined. For some keto selenides, it is advantageous to add pyridine as buffer, and we routinely do this. Important exceptions are some of the $\beta$-dicarbonyl enones which are sensitive to base catalyzed epoxidation by hydro- gen peroxide. If the amount of $\mathrm{H}_{2} \mathrm{O}_{2}$ is carefully controlled ( 2 equiv), even the very sensitive 2 -carbethoxycyclopentenone (run 35) can be prepared. The selenoxide elimination is the only satisfactory procedure in the literature for the preparation of this compound $\mathrm{d}^{2 \mathrm{~b}}$ and the related 2-acetyland 2-carbethoxycyclohexenones (runs 34, 36-38). ${ }^{1 \mathrm{f}, \mathrm{g}}$

The fate of the selenium depends on the oxidation conditions. When 1 equiv of oxidant is used, the benzeneselenenic acid $(\mathrm{PhSeOH})$ disproportionates to a $1: 1$ ratio of benzeneseleninic acid $\left(\mathrm{PhSeO}_{2} \mathrm{H}\right)$ and $\mathrm{Ph}_{2} \mathrm{Se}_{2}$. With excess oxidant, $\mathrm{PhSeO}_{2} \mathrm{H}\left(\mathrm{p} K_{\mathrm{a}} 4.70^{23}\right)$ is the only product. When weakly acidic conditions are undesirable, the reaction mixture can be buffered with pyridine to ensure near neutral conditions.

$$
3 \mathrm{PhSeOH} \longrightarrow \mathrm{PhSeSePh}+\mathrm{PhSeO}_{2} \mathrm{H}+\mathrm{H}_{2} \mathrm{O}
$$

The seleninic acid is nonvolatile and is removed during aqueous work-up by base extraction. The diselenide can on occasion cause separation problems. It is nonpolar and can be separated chromatographically where this is feasible. The benzeneseleninic acid can easily be reduced to $\mathrm{PhSe}$ $\mathrm{SePh}^{\text {sd }}$ (see Experimental Section), which can be recovered in high yield.

The Elimination Reaction. The selenoxide elimination is not uniformly successful in all systems, but the following generalizations may be helpful. Assuming that the selenide can be formed in satisfactory yield, acyclic ketones can be converted to enones in high yield, practically without exception. Cyclic $\alpha$-phenylseleno ketones fully substituted at the carbon bearing selenium can almost invariably be converted to enones in excellent yield. The only exception we have encountered is 5. The high reactivity of the expected product may be at least in part responsible for the failure to isolate enone in detectable yield for this example.

Little information is available on the rates of selenoxide eliminations, but we have made the qualitative observation 
<smiles>O=C(c1ccccc1)C1([AsH2])CC1</smiles>

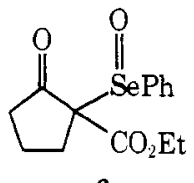

6

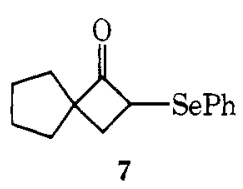

that the carbonyl group significantly accelerates the elimination compared with simple alkyl selenoxides. We have similarly observed that the ethylene ketals of keto selenoxides (see below) undergo significantly slower elimination than the keto selenoxides themselves. The accelerating effect is even more pronounced for selenoxides derived from $\beta$-dicarbonyl compounds. Here the elimination is rapid well below $0^{\circ}$ and for 6 appears to occur even at $-78^{\circ}$. Similar trends are clearly present in sulfoxide eliminations. ${ }^{10}$

Cyclic systems where the carbon bearing selenium also bears a hydrogen are subject to side reactions which lower the yield to varying extent depending on reaction conditions and subtle conformational and other factors in the substrate. Apparently the cyclic transition state ${ }^{3,5 a}$ for the syn elimination conflicts to a greater or lesser extent with conformational preferences of the cyclic ketone.

A four-membered cyclic system in which the selenide is tertiary (run 9) gives cyclobutene in good yield. The reaction is still feasible for the preparation of 3-phenylcyclobutenone (run 10), but compound $7^{24}$ gives no detectable cyclobutenone on oxidation. It is not clear whether no product is formed or whether that which is formed is destroyed subsequent to elimination. 2-Benzylcyclopentanone can be converted to 5-benzylcyclopent-2-enone in fair yield (run 11). Note that an almost quantitative yield of the isomeric enones is formed from the tertiary selenide (run 12). The yields of cyclohexenones vary from fair to good depending on substituents and reaction conditions. Cycloheptenone and cyclooctenone are formed in very low yield when oxida. tion of the respective selenides with hydrogen peroxide at room temperature (method $\mathrm{A}$ or $\mathrm{B}$ ), ozonization followed by slow warm-up to $25^{\circ}$ (method C), or oxidation with sodium metaperiodate is employed. The conversion of 2-cycloheptenone to cyclohepta-2,6-dienone, however, proceeds without complication, possibly because the ring is flattened by the two additional $\mathrm{sp}^{2}$ carbons in the ring. This could make the cycloelimination occur more readily. A similar effect may be responsible for the somewhat higher yield obtained for 2-p-tolyidenecyclohexanone (run 19) when compared with those of the other cyclohexanones.

We have attempted to improve yields for the cyclic enones by determining the nature of the side reactions which are occurring. This information should then be of use in modifying substituents or reaction conditions to eliminate by-products. Most of these studies were carried out using 2-arylselenocyclooctanones (8), although cycloheptanone

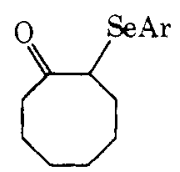

8

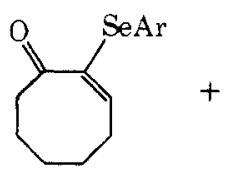

10

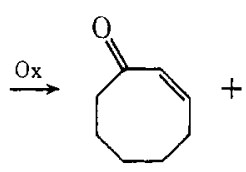

9
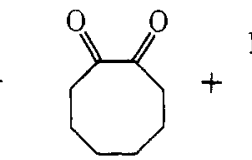

11

$\mathrm{Ar}=\mathrm{C}_{6} \mathrm{H}$

b, $\mathrm{Ar}=m-\mathrm{CF}_{3} \mathrm{C}_{6} \mathrm{H}_{4}$
Table II. Product Yields from the Oxidation of 2-Arylselenocyclooctanone (8)

\begin{tabular}{|c|c|c|c|c|}
\hline \multirow[b]{2}{*}{ Oxidizing conditions } & \multicolumn{4}{|c|}{ Yields $a$} \\
\hline & 9 & 10 & 11 & 12 \\
\hline \multicolumn{5}{|l|}{ Aryl = phenyl $(\mathbf{8 a})$} \\
\hline $\mathrm{NaIO}_{4}-\mathrm{NaHCO}_{3}$ & 14 & 48 & $b$ & $b$ \\
\hline Method B & 16 & 2 & 13 & 39 \\
\hline Method $\mathrm{C}^{\mathrm{C}}$ & 39 & 8 & 43 & $b$ \\
\hline Method D, HN-i-Pra ${ }_{2} d$ & 67 & 14 & $<2$ & $b$ \\
\hline Method D, $\mathrm{HNEt}_{2}$ & 74 & $<2$ & $<2$ & $b$ \\
\hline \multicolumn{5}{|l|}{ Aryl $=3-\mathrm{CF}_{3} \mathrm{C}_{6} \mathrm{H}_{4}(\mathbf{8 b})$} \\
\hline Method B & 27 & 0 & 5 & 44 \\
\hline Method $\mathrm{C}^{\mathrm{C}}$ & 39 & 14 & 32 & $b$ \\
\hline Method D, HN-i-Pr & 69 & 22 & $<2$ & $b$ \\
\hline
\end{tabular}

$a$ Absolute yields. $b$ The yield was not determined for these products. $c$ No pyridine was added during selenoxide elimination; $2-5 \%$ of 8 was recovered during these runs. $d$ Preparative scale reaction gave $56 \%$ yield of 9 .

and 2-methylcyclohexanone were also used. We have isolated and characterized two major types of by-products ${ }^{4 b}$ formed in cyclic systems: $\alpha$-arylseleno enones (10) and $\alpha$ diketones (11). When hydrogen peroxide is used, acyclic dicarboxylic acids (12) are also formed, probably by further oxidation of the diketone. ${ }^{25}$ The replacement of phenylseleno by benzylseleno in $\mathbf{8}$ does not improve the ratio of elimination to side reactions. However, the use of more strongly electron-withdrawing groups $(\mathbf{8 b})$ increases the rate of syn elimination ${ }^{26}$ and gives some improvement in yield of enone with hydrogen peroxide as oxidant (Table II), although still not to synthetically useful levels for cycloheptenone or cyclooctenone. Attempts to improve yields by changing $\mathrm{pH}$ during sodium metaperiodate oxidation also failed.

A procedure which sacrifices some of the mildness of the usual conditions but dramatically improves the reaction in some cases, was the following: the selenide was ozonized at $-78^{\circ}$ and then added while cold to refluxing carbon tetrachloride containing diisopropylamine (method D, see runs 21 and 22, Table I; Table II). Unfortunately, this procedure is not the whole answer. Yields are still less than quantitative for the more troublesome systems, and no improvement was obtained for 2-phenylcyclohexanone (runs 16 and 17).

Small amounts of $\alpha$-phenylseleno enones are still formed using method D, but less than $2 \%$ of $\alpha$-diketone is present (see Table II). This lends support to our postulate ${ }^{4 b}$ that Pummerer-like reactions are responsible for $\alpha$-diketone formations. The base prevents protonation of the selenoxide (13, Scheme II).

Under highly acidic conditions, the Pummerer reaction is the only pathway observed. No enone is formed (eq 7 gives

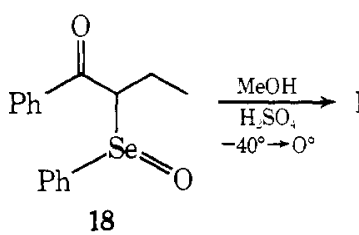

18<smiles>CCC([GeH2]c1ccccc1)C(=O)c1ccccc1</smiles>

$68 \%$<smiles>COC(CCl)(OC)C(=O)Nc1ccccc1</smiles>

$22 \%$ an example). This reaction also illustrates another problem that arises under acidic conditions-the occurrence of redox reactions. The hydrolysis of the presumed Pummerer intermediate (e.g., 14) gives benzeneselenol, which reduces selenoxides to selenides. Small amounts of reduction were observed for method $\mathrm{C}$ (Table II). Under these conditions, the $\mathrm{PhSeO}_{2} \mathrm{H}$ formed makes the reaction mixture slightly acidic. Redox reactions are also illustrated in eq 8 , again under the conditions of method $C$. Such redox reactions are com- 
Scheme II

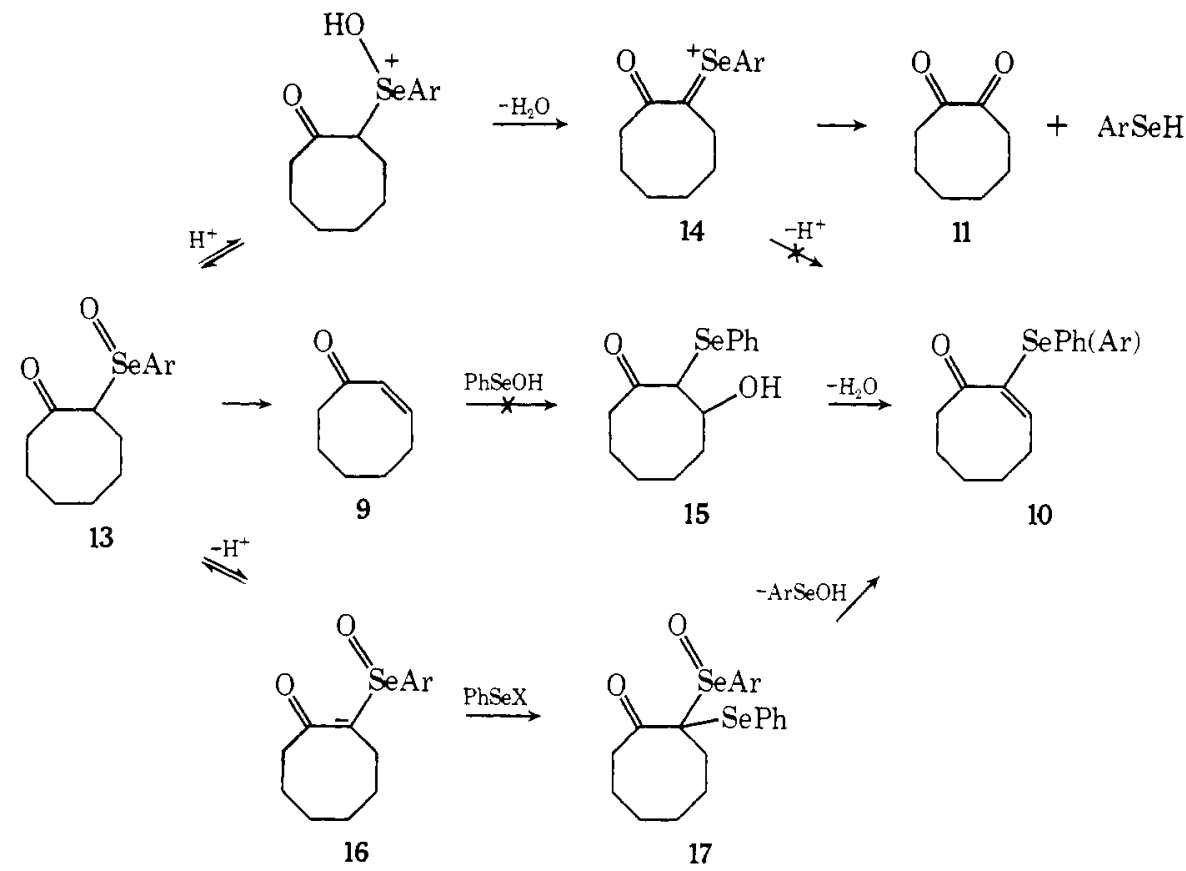

pletely suppressed under mildly basic conditions (pyridine or diisopropylamine).

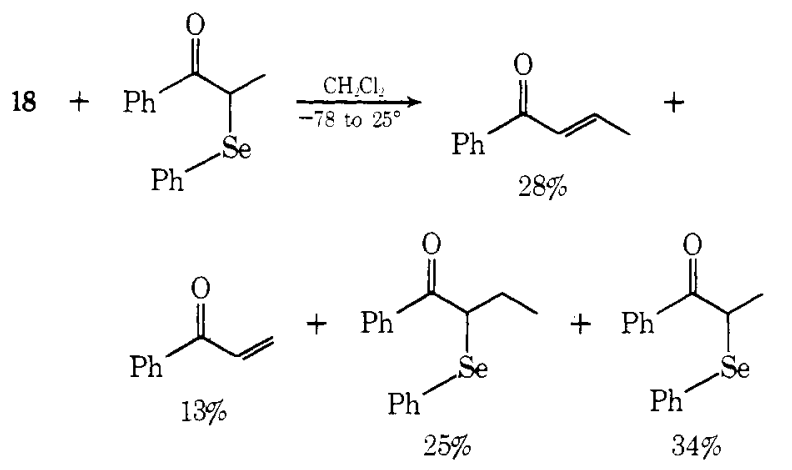

The formation of 2-phenylseleno-2-cycloocten-1-one (10a) could conceivably occur by three mechanisms (eq 4 , 5 , and 6, in Scheme II). The first involves deprotonation of the Pummerer intermediate (14); the second involves addition of selenenic acid to enone, followed by dehydration (eq 5 ). This mechanism seemed unlikely (conditions were sufficiently mild that the hydroxyl compound 15 should have been isolated) and could be ruled out by generating $\mathrm{PhSeOH}$ (by elimination of 18 ) in the presence of cyclooctenone (9); no 10a was formed. ${ }^{27}$ The third plausible mechanism (eq 6) involves reaction of the stabilized enolate $\mathbf{1 6}$ (or the enol) with some selenenylating agent, most probably $\mathrm{PhSeO}-\mathrm{SePh}$ produced during the disproportionation of $\mathrm{PhSeOH}$ ( $\mathrm{PhSO}-\mathrm{SPh}$ is formed during the disproportionation of $\mathrm{PhSOH}$; it behaves as a sulfenylating reagent ${ }^{28}$ ). The intermediate 17 would then undergo selenoxide elimination. Oxygen scrambling between the two arylseleno groups is unlikely, at least under basic conditions.

A straightforward test for the above mechanism is based on the fact that the arylseleno group in 10, formed according to eq 6 , would not be the same one originally present in 13 whereas, in eq 4 , the carbon-selenium bond is never broken. We thus carried out the elimination reaction on a mixture of two different arylselenino ketones. The acyclic selenoxide 18 undergoes high-yield elimination under most conditions. It was used as an in situ source of $\mathrm{PhSeOH}$.
Table III. Cross Over Experiments

\begin{tabular}{cccc}
\multicolumn{4}{c}{$13 \mathrm{~b}+18 \stackrel{\Delta}{\rightarrow} 9+10$} \\
\cline { 2 - 4 } Ratio & 9 & Relative yields $a$ \\
$13 \mathrm{~b}: 18$ & 76 & 24 & $10 \mathrm{~b}$ \\
\hline $1: 0^{b}$ & 43 & 15 & 42 \\
$1: 1^{b}$ & 25 & 7 & 68 \\
$1: 4^{b}$ & 74 & 26 & \\
$1: 0^{c}$ & 43 & 17 & 40 \\
$1: 1^{c}$ & 45 & 9 & 46 \\
$1: 4^{c}$ & & 9 & \\
\hline
\end{tabular}

$a$ Relative yields (NMR integration) of products 9 and 10 only are shown. $b$ Elimination by method $\mathrm{D}\left(\mathrm{HN}-i-\mathrm{Pr}_{2}\right) . c$ Elimination by method $\mathrm{C}$. The absolute yields are considerably lower (see Table II) than for method D.

Some results of crossover experiments are summarized in Table III. Reversing the aryl groups gave similar results. The formation of the crossover product $10 \mathbf{a}$ from $13 \mathbf{b}$ is fully consistent with the mechanism of eq 6 , even to the extent of a pronounced decrease in the relative yield of enone 9 when more $\mathrm{PhSeX}$ is present to react with enolate 16. Clearly, the formation of $\mathbf{1 0}$ according to eq 6 could be prevented by the presence of a nucleophile which reacts more rapidly with $\mathrm{PhSeO}-\mathrm{SePh}$ than does 16 . In fact, if the selenoxide elimination is carried out in the presence of diethylamine (rather than diisopropylamine) using method D, the formation of $\mathbf{1 0}$ is completely suppressed (Table II). Only moderate increases in yields of enones are obtained, however (runs 22 and 23). The selenenamide $\left(\mathrm{PhSeNEt}_{2}\right)$ is formed in high yield under these conditions. The reaction in the presence of $\mathrm{HN}-i-\mathrm{Pr}_{2}$ also gives the selenenamide ( $\mathrm{PhSeN}-i-\mathrm{Pr}_{2}$ ), but formation of $\mathbf{1 0}$ is not prevented. Apparently disopropylamine is of lower or comparable reactivity toward $\mathrm{PhSeO}-\mathrm{SePh}$ than 16, whereas diethylamine is much more reactive than 16.

Thus in the presence of an unhindered secondary or primary amine, the formation of by-product $\alpha$-diketones and $\alpha$-phenylseleno enones can be prevented, although at some cost in the mildness of the reaction conditions; i.e., with reactive enones, products resulting from Michael addition of the amine (and of selenenamide) may be formed. We have not been able to find a trapping agent for $\mathrm{PhSeX}$ which 
does not have the potential of participating in Michael additions.

Our conclusion that the activating effect of the carbonyl function is required for the formation of by-products is supported by the observation that the ketals 19 and 20 are formed in good yield by selenoxide elimination, ${ }^{4 b, 29}$ whereas the $\alpha$-phenylseleno ketones themselves do not undergo clean elimination under comparable conditions. By similar reasoning, esters should be less prone toward these side reactions than ketones, because of the lower acidity of the $\alpha$ hydrogen. In fact, an $\epsilon$-lactone (run 31 ) can be successfully dehydrogenated (compare run 21 ).

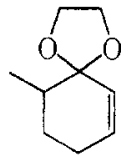

19

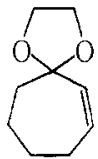

20
In summary, given the successful preparation of an $\alpha$ phenylseleno carbonyl compound, the following is suggested: if products are stable to hydrogen peroxide, use method A or preferably method B; if not, try method C (pyridine) or $\mathbf{D}$ (diisopropylamine). If seleno enone formation is a problem, try method $\mathrm{D}$ with diethylamine. If above methods fail, or if selective ozonization is difficult, try sodium metaperiodate in aqueous methanol, with or without sodium bicarbonate. Other potentially useful oxidizing agents which we have not explored in detail are tert-butyl hydroperoxide, peracetic acid, ${ }^{5 c}$ and $\mathrm{MoO}_{5}$.Py.HMPA. ${ }^{30}$

We have briefly explored the deselenation of $\alpha$-phenylseleno enones as an approach to improving the yields of enones. Selenium dioxide dehydrogenation of ketones ${ }^{2}$ often gives selenium containing by-prodúcts. Kocor and TuszyMaczka ${ }^{31 a}$ found that these by-products could be removed and yields improved by treatment of the oxidation products with ammonium sulfide. The structure of these by-products has not been often determined, but Marx and Norman $3 \mathrm{lb}$ recently reported the isolation of $\mathbf{2 1}$ in $14 \%$ yield. If one as-<smiles>CC1(C)C=CC(=O)CC1</smiles><smiles>CC1(C)C=CC(=O)C=C1</smiles>

22<smiles>CC1(C)C=CC(=O)C([Se][Se]C2=CC(C)(C)C=CC2=O)=C1</smiles>

21 sumes that by-products like $\mathbf{2 1}$ are usually formed during $\mathrm{SeO}_{2}$ oxidations, then the ammonium sulfide purification results imply that analogs of $\mathbf{2 1}$ were deselenated to enones by this reagent. Accordingly, we have treated the $\alpha$-phenylseleno enone 23 with $\left(\mathrm{NH}_{4}\right)_{2} \mathrm{~S}$ as well as $\mathrm{PhSeLi}$ and find

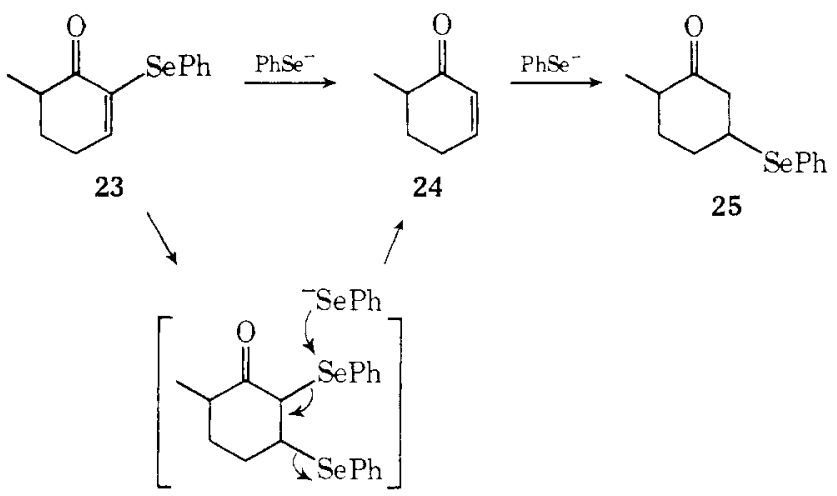

that both reagents do result in the conversion to enone (24). Apparently, Michael reaction subsequently leads to $\mathbf{2 5}$ since 24 disappears at a rate comparable to its rate of formation from 23. Oxidation of the reaction mixture gives back enone 24 by selenoxide elimination of 25 . We postulate that this deselenation proceeds as shown (see eq 2).

The product 21 isolated by Marx and Norman is quite analogous to the by-products we have found in the selenoxide elimination and may actually be formed by a similar mechanism.

Reaction of Benzeneseleninyl Chloride (26) with Enolates. Difficulties with the oxidation in several systems led us to explore the utility of benzeneseleninyl chloride (26) as a

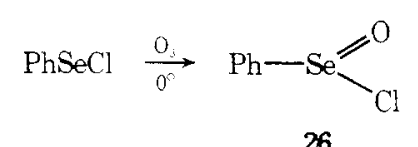

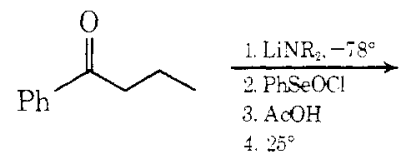<smiles>C/C=C/C(=O)c1ccccc1</smiles>

seleninylating agent. This compound is prepared by ozonization of $\mathrm{PhSeCl}^{22 \mathrm{~b}}$ and was conveniently isolated by crystallization. The reagent is very hygroscopic and, to avoid hydrolysis, contact with moist air must be avoided. This is a major disadvantage of this reagent; crystalline $\mathrm{PhSeBr}$ or $\mathrm{PhSeCl}$ can be handled in air with no special precautions.

Ketone and other enolates undergo C-seleninylation with 26, and satisfactory yield of enone can be obtained in some cases (Method E, Table I, runs 5 and 30). Yields are rather variable, however, and frequently lower than obtained by the two-step procedure. Major by-products which are formed are starting ketone and $\alpha$-phenylseleno ketone. The use of amine-free solutions of sodium or potassium enolates (from the reaction of carbonyl compounds with $\mathrm{NaH}$ or $\mathrm{KH})$ did not improve matters significantly. The use of benzeneseleninyl chloride is recommended only when the normal selenide oxidation procedure fails because of competing or preferential oxidation elsewhere in the molecule.

\section{Conclusion}

The methods described here, together with related published procedures employing the selenoxide elimination, ${ }^{4-8}$ provide techniques for the preparation of $\alpha, \beta$-unsaturated carbonyl compounds and nitriles under uniquely mild conditions. A wide range of carbonyl compounds can be dehydrogenated, and good control of positional selectivity in unsymmetric ketones can often be achieved.

The power of the method is shown in the conversion of $\beta$-dicarbonyl compounds to sensitive $\beta$-dicarbonyl enones (runs 32 to 40 ), for which the dehydrobromination often fails completely. $1 \mathrm{f}, \mathrm{g}$ The procedure described here effects this conversion in excellent yield for most systems, with the further advantage that products are not detectably converted to the often more stable enol forms. ${ }^{1 \mathrm{f}, \mathrm{g}}$

We have tried to explore in some detail the limitations of the methods described here. There are systems where the reaction fails to give high yields, and the results reported here should permit anticipation of systems where difficulties may be encountered and lead to quick selection of appropriate procedures to optimize yields.

The closely related sulfoxide elimination procedure developed by Trost and Salzmann ${ }^{10}$ does not suffer from the necessity of working with toxic compounds and appears to be somewhat less prone to side reactions. The advantages of the selenoxide route, however, include the almost ideal stoichiometry of the selenenylation reaction (which compensates for the somewhat higher expense of the reagent), the 
mildness of the selenenylation reaction, and, of course, the extreme mildness of the olefin forming step (Jones, Mundy, and Whitehouse ${ }^{3}$ have reported that the selenoxide elimination proceeds at $\mathrm{ca} .80-100^{\circ}$ lower temperatures than the sulfoxide elimination). This point is illustrated in run 41 , where an $\alpha$-phenylsulfino- $\alpha$-phenylselenino ketone undergoes selenoxide elimination to give a vinyl sulfoxide. A further advantage of the selenoxide route is the great reluctance of selenoxides to undergo further oxidation to selenones so that a wide range of oxidants is available, and these may be used in excess.

\section{Experimental Section}

Nuclear magnetic resonance spectra were obtained on a Varian A-60A, Joel MH-100, or Brucker WH270 spectrometer. Infrared spectra were obtained on a Beckman IR-8 or Perkin-Elmer IR-267 spectrophotometer and mass spectra on an AEI MS-902 spectrometer. Unless specified otherwise, NMR and ir spectra were measured in $\mathrm{CCl}_{4}$ solution.

Starting materials were commercially available or prepared according to the literature references cited. $n$-Butyllithium in hexane was purchased from Foote Mineral Co. or Alfa. Tetrahydrofuran (THF) was freshly distilled from lithium aluminum hydride; diisopropylamine was distilled from potassium hydroxide and stored over 4A molecular sieves. All reactions involving ketone or ester enolates were run under an atmosphere of dry nitrogen.

Preparative thin layer chromatography (preparative TLC) was carried out using Merck PF-254 silica gel, with 10\% ether-pentane as eluent unless indicated otherwise.

Elemental analyses were performed according to the procedure of Gould ${ }^{32}(\mathrm{Se})$ or by Spang Microanalytical Laboratories $(\mathrm{C}, \mathrm{H})$.

The normal work-up procedure involved addition of the reaction mixture to $30 \mathrm{ml}$ of $50 \%$ ether-pentane and $30 \mathrm{ml}$ of saturated $\mathrm{NaHCO}_{3}$ solution. The aqueous layer was separated and washed with ether, and the combined organic portions were washed with $10 \% \mathrm{HCl}$ if amine is present and with saturated $\mathrm{NaCl}$ solution and dried by filtering through a cone of $\mathrm{Na}_{2} \mathrm{SO}_{4}$. Solvent was removed on a rotary evaporator.

CALTION. Selenium containing compounds are toxic and should be handled with due care. Most of the selenium containing compounds described here are sufficiently high boiling that volatility does not pose a severe toxicity or odor problem. $\mathrm{PhSeCl}$ and $\mathrm{PhSeBr}$, however, are volatile enough to have pronounced odors.

Oxidation Procedures. Typical experimental procedures for the oxidations are given below: method A (run 28 and ref 4a), method $B$ (runs $4,6,9,34$, and 35 ), method $C$ (runs 10,31 , and 37), method D (run 15), method $\mathrm{E}$ (run 5), $\mathrm{NaIO}_{4}$ (run 1), m-chloroperbenzoic acid (run 38 )

The oxidation of divalent selenium compounds using hydrogen peroxide is highly exothermic and appears to be autocatalytic (i.e., $\mathrm{PhSeO}_{2} \mathrm{H}$ is a catalyst, either because of its acidity or through the formation of $\mathrm{PhSeO}_{3} \mathrm{H}$ ). Under no conditions should oxidations of amounts greater than $5 \mathrm{mmol}$ be carried out by adding the full amount of $\mathrm{H}_{2} \mathrm{O}_{2}$ before oxidation has commenced (see runs 4 and 6 for larger scale oxidations).

Lithium Diisopropylamide. Solutions of LDA in THF were usually prepared as needed (see run 1). For small scale experiments, preformed solution was convenient, prepared as follows: a dry septum-capped flask was flushed with nitrogen and cooled to $-78^{\circ}$. THF $(8 \mathrm{ml})$ and diisopropylamine $(7.9 \mathrm{ml})$ were added, followed by $40 \mathrm{ml}$ of $1.40 \mathrm{M} n$-butyllithium in hexane. The $1 \mathrm{M}$ LDA solution was warmed to $0^{\circ}$ and stored at that temperature. It keeps indefinitely if air and moisture are carefully excluded.

Diphenyl Diselenide. This procedure is based on the organic synthesis preparation of benzeneselenol. ${ }^{33 a}$ We have used the air oxidation of benzeneselenol developed by Sharpless and Young, ${ }^{5 b, e}$ or the alternative procedure below, which is essentially odorless since it avoids the necessity for acid work-up of the Grignard reaction, during which hydrogen selenide and benzeneselenol are liberated.

To a 2-1. three-neck flask purged with nitrogen (condenser, mechanical stirrer, 250-ml addition funnel) were added $24.0 \mathrm{~g} \mathrm{(1}$ mol) of $\mathrm{Mg}$ turnings, $50 \mathrm{ml}$ of anhydrous ether, and $30 \mathrm{ml}$ of a solution of $160 \mathrm{~g}(1.02 \mathrm{~mol})$ of bromobenzene in $100 \mathrm{ml}$ of ether. When the Grignard reaction had started, $400 \mathrm{ml}$ of ether was added; the remainder of the bromobenzene solution was added over a period of $30 \mathrm{~min}$. The solution was refluxed for an additional $30 \mathrm{~min}$ after completion of the addition. The addition funnel was replaced by a $\mathrm{Y}$ adapter, and $74 \mathrm{~g}(0.94 \mathrm{~mol})$ of grey powdered selenium was added during $15 \mathrm{~min}$ in small portions through one arm of the $\mathrm{Y}$ tube, while nitrogen purge was continued through the other. The reaction was again refluxed for $30 \mathrm{~min}$ after completion of the selenium addition.

The flask was placed in an ice bath, and $23.5 \mathrm{ml} \mathrm{(70} \mathrm{g,} 0.435$ mol) of bromine was added dropwise at a rate such that the solution did not reflux. A solution of $53.5 \mathrm{~g}(1 \mathrm{~mol})$ of $\mathrm{NH}_{4} \mathrm{Cl}$ in 150 $\mathrm{ml}$ of water was then slowly added, while vigorous stirring was continued. The ether layer was decanted from the precipitated magnesium salts and gravity filtered, the salts were washed with three $50-\mathrm{ml}$ portions of ether, and the ether was evaporated on the steam bath. After most of the ether had evaporated, air was blown through the hot solution for $10 \mathrm{~min}, 500 \mathrm{ml}$ of hexane was added, and the solution was again filtered if necessary and allowed to crystallize overnight at $5^{\circ}$. If the crystallized diphenyl diselenide was red (due to the presence of small amounts of amorphous selenium), it was redissolved by swirling and warming gently, filtered, and again allowed to crystallize. Filtration gave $82 \mathrm{~g}$ (56\% yield) of yellow diphenyl diselenide, $\mathrm{mp} 60-62^{\circ}$ (lit. ${ }^{33 \mathrm{~b}} \mathrm{mp} 63.5^{\circ}$ ). A second crop $(14 \mathrm{~g})$ can be obtained by concentration of the mother liquor to $200 \mathrm{ml}$, for a total yield of $66 \%$. Material prepared in this way contains a small amount of selenium (probably as diphenyl triselenide) but is adequate for most purposes.

Diphenyl diselenide can be recovered in high yield from applications such as those described below. A procedure for reduction of the $\mathrm{PhSeO}_{2} \mathrm{H}$ and recovery of $\mathrm{Ph}_{2} \mathrm{Se}_{2}$ is given in the Experimental Section following run 6 .

Benzeneselenenyl Chloride. Chlorine gas was passed into a magnetically stirred solution of $25.0 \mathrm{~g}(80 \mathrm{mmol})$ of $\mathrm{Ph}_{2} \mathrm{Se}_{2}$ in $190 \mathrm{ml}$ of hexane until the weight had increased by $5.4 \mathrm{~g}$. The white precipitate of $\mathrm{PhSeCl}_{3}$ which forms at the entrance point of the chlorine does not redissolve when the end point is passed - this can be used to determine the correct amount of chlorine (if excess chlorine was added, the $\mathrm{PhSeCl}_{3}$ can be removed by addition of a further small quantity of $\mathrm{Ph}_{2} \mathrm{Se}_{2}$ ). The solution was heated to dissolve any crystallized $\mathrm{PhSeCl}$ (if the solution is cloudy at this point, it should be filtered) and allowed to crystallize $\left(0^{\circ}\right)$, giving $27.3 \mathrm{~g}$ (89\%) of $\mathrm{PhSeCl}$ as large orange crystals, mp 62-64. (lit. ${ }^{33 \mathrm{c}} \mathrm{mp}$ $64-65^{\circ}$ ). If the starting $\mathrm{Ph}_{2} \mathrm{Se}_{2}$ was pure, a second crop can be obtained, giving an almost quantitative yield

Benzeneselenenyl Bromide. ${ }^{3 \mathrm{~d} d}$ This compound was usually prepared in situ and used directly. A typical procedure for $12 \mathrm{mmol}$ of $\mathrm{PhSeBr}$ is as follows: $1.88 \mathrm{~g}(6 \mathrm{mmol})$ of $\mathrm{Ph}_{2} \mathrm{Se}_{2}$ were dissolved in $5 \mathrm{ml}$ of THF, and $0.324 \mathrm{ml}(0.96 \mathrm{~g}, 6 \mathrm{mmol})$ of $\mathrm{Br}_{2}$ were added dropwise with stirring. The reaction is essentially instantaneous, and the solution can be used directly. Larger scale preparations require cooling $\left(10^{\circ}\right)$, because the reaction is slightly exothermic.

Benzeneseleninyl Chloride (26). A solution of $5.0 \mathrm{~g}(26 \mathrm{mmol})$ of $\mathrm{PhSeCl}$ in $25 \mathrm{ml}$ of dichloromethane was ozonized through a $\mathrm{CaSO}_{4}$ drying tube at $-5^{\circ}$ until the color has faded to a light yellow. The solution was warmed to $25^{\circ}$, and the drying tube was replaced by a septum in a dry bag. Care must be taken to avoid moisture since the chloride is extremely hygroscopic. After crystallization at $-24^{\circ}$ overnight, the mother liquor was transferred by cannula to a flask equipped with a septum. The pale white crystals were washed with $5 \mathrm{ml}$ of cold dichloromethane, which was added to the mother liquor. After drying in vacuo for $2 \mathrm{hr}, 2.81 \mathrm{~g}$ of nearly white crystals were obtained, $\mathrm{mp} 56-64^{\circ}$ (lit. ${ }^{22 \mathrm{~b}} \mathrm{mp} 75^{\circ}$ ). A second crop $(2.12 \mathrm{~g})$ was obtained by adding $10 \mathrm{ml}$ of cold hexane to the mother liquor and cooling overnight at $-24^{\circ}$ for a combined yield of $92 \%$.

Anal. Calcd for $\mathrm{C}_{6} \mathrm{H}_{5} \mathrm{ClOSe}: \mathrm{Se}, 38.07$, Found: $\mathrm{Se}, 37.82$.

3,3'-Bis(trifluoromethyl)diphenyl Diselenide. A 1-1. three-neck round-bottomed flask was fitted with a reflux condenser, a mechanical stirrer, a dropping funnel, and a nitrogen inlet tube. The exit tube is attached to an $\mathrm{NaOH}$ bubbler. $m$-Trifluoromethylphenylmagnesium bromide was prepared using $28.1 \mathrm{~g}(0.125 \mathrm{~mol})$ of $m$-bromobenzotrifluoride, $3.0 \mathrm{~g}(0.125 \mathrm{~mol})$ of magnesium turnings, and $250 \mathrm{ml}$ of dry ether. The dropping funnel was removed, and $9.5 \mathrm{~g}(0.12 \mathrm{~mol})$ of powdered black selenium was added gradually over a 10 -min period through the side arm. It is important to 
avoid the introduction of oxygen during this operation. After stirring for an additional $20 \mathrm{~min}, 100 \mathrm{~g}$ of ice were slowly added to the flask followed by $20 \mathrm{ml}$ of concentrated $\mathrm{HCl}$. The reaction mixture was worked up (water wash), $100 \mathrm{ml}$ of methanol was added to the yellow solution, and air was bubbled through overnight. Distillation of the residue gave $23.2 \mathrm{~g}(88 \%)$ of diselenide, an orange liquid, bp $121-123^{\circ}(0.25 \mathrm{~mm})$.

Anal. Calcd for $\mathrm{C}_{14} \mathrm{H}_{8} \mathrm{~F}_{6} \mathrm{Se}_{2}: \mathrm{Se}, 35.24$. Found: $\mathrm{Se}, 35.10$.

4,4'-Bis(trifluoromethyl)diphenyl Diselenide. Following the procedure outlined to prepare the $3,3^{\prime}$ isomer, $5.62 \mathrm{~g}(25 \mathrm{mmol})$ of bromide gave $2.52 \mathrm{~g}$ ( $45 \%$ ) of the yellow diselenide after recrystallization from methanol $\left(\mathrm{mp} 53-55^{\circ}\right)$.

Anal. Calcd for $\mathrm{C}_{14} \mathrm{H}_{8} \mathrm{~F}_{6} \mathrm{Se}_{2}$ : Se, 35.24. Found: Se, 34.90.

3-Trifluoromethylbenzeneselenenyl Chloride. To a solution of $4.48 \mathrm{~g}(10 \mathrm{mmol})$ of diselenide in $10 \mathrm{ml}$ of dichloromethane at $25^{\circ}$ under nitrogen was added, dropwise, a solution of $1.35 \mathrm{~g}$ (10 $\mathrm{mmol}$ ) of $\mathrm{SO}_{2} \mathrm{Cl}_{2}$ in $1 \mathrm{ml}$ of dichloromethane with stirring over a 15 -min period. Solvent was removed under vacuum, and distillation gave $4.62 \mathrm{~g}(89 \%)$ of chloride, a dark orange liquid, bp $54-55^{\circ}$ $(0.25 \mathrm{~mm})$.

Anal. Calcd for $\mathrm{C}_{7} \mathrm{H}_{4} \mathrm{ClF}_{3} \mathrm{Se}$ : Se, 30.42. Found: $\mathrm{Se}, 30.07$.

$(Z)$-1-Acetoxy-1-phenylpropene. This compound was prepared by treatment of the lithium enolate of propiophenone with acetic anhydride and purified by distillation and recrystallization from pentane: $\mathrm{mp} 29-30.5^{\circ}$; NMR $\delta 1.63(\mathrm{~d}, J=7.2 \mathrm{~Hz}, 3 \mathrm{H}), 2.13$ (s, $3 \mathrm{H}), 5.73(\mathrm{q}, J=7.2 \mathrm{~Hz}, 1 \mathrm{H}), 7.1-7.5(\mathrm{~m}, 5 \mathrm{H})$; ir 1762,1207 $\mathrm{cm}^{-1}$.

1-Phenyl-2-phenylseleno-1-propanone (2). A. Run 1. The following serves as a typical procedure for the preparation of an $\alpha$ phenylseleno ketone via the lithium enolate. Into a $50-\mathrm{ml}$ two-neck round-bottomed flask (magnetic stirrer, septum, 10-ml addition funnel) was distilled $20 \mathrm{ml}$ of THF under nitrogen. The flask was cooled to $-78^{\circ}$, and $0.92 \mathrm{ml}(6.0 \mathrm{mmol})$ of disopropylamine were added, followed by $2.94 \mathrm{ml}$ of $2.05 \mathrm{M} \mathrm{n}$-BuLi in hexane. A solution of propiophenone $(0.67 \mathrm{~g}, 5 \mathrm{mmol})$ in $2 \mathrm{ml}$ of THF was added dropwise, and the solution was stirred for $15 \mathrm{~min}$. Into the addition funnel was placed $0.94 \mathrm{~g}(3.0 \mathrm{mmol})$ of $\mathrm{Ph}_{2} \mathrm{Se}_{2}$, and this was dissolved in $2 \mathrm{ml}$ of THF. Bromine $(0.162 \mathrm{ml}, 0.48 \mathrm{~g}, 3.0 \mathrm{mmol})$ was added dropwise to the solution, which was agitated briefly to dissolve any $\mathrm{PhSeBr}_{3}$ formed. The $\mathrm{PhSeBr}$ solution was added rapidly to the enolate solution (immediate decolorization), and the cold reaction mixture was poured into $50 \mathrm{ml}$ of $0.5 N \mathrm{HCl}$ and $40 \mathrm{ml}$ of $50 \%$ ether-pentane. The organic layer was washed with water, saturated $\mathrm{NaHCO}_{3}$ solution, and saturated $\mathrm{NaCl}$ solution and dried by filtering through a cone of anhydrous $\mathrm{Na}_{2} \mathrm{SO}_{4}$. Solvent was removed, and the crude product was crystallized from ether-pentane at $-20^{\circ}\left(0.87 \mathrm{~g}, \mathrm{mp} 36.5-37^{\circ}\right)$. Chromatography of the mother liquor gave a further $0.40 \mathrm{~g}$, isolated by crystallization (total yield $1.27 \mathrm{~g}, 87 \%)$ : NMR $\delta 1.60(\mathrm{~d}, J=7.0 \mathrm{~Hz}, 3 \mathrm{H}), 4.58(\mathrm{q}, J=7.0$ $\mathrm{Hz}, 1 \mathrm{H}), 7.1-7.6(\mathrm{~m}, 8 \mathrm{H}), 7.88(\mathrm{~m}, 2 \mathrm{H})$; ir $1680,1598,1582$ $\mathrm{cm}^{-1}$.

Anal. Calcd for $\mathrm{C}_{15} \mathrm{H}_{14} \mathrm{OSe}$ : C, 62.29; H, 4.88. Found: $\mathrm{C}, 62.23$; $\mathrm{H}, 4.95$.

To a solution of $1.00 \mathrm{~g}(3.46 \mathrm{mmol})$ of 1 -phenyl-2-phenylseleno1 -propanone (2) in $60 \mathrm{ml}$ of methanol was added $10 \mathrm{ml}$ of $\mathrm{H}_{2} \mathrm{O}$, $0.35 \mathrm{~g}(4 \mathrm{mmol})$ of $\mathrm{NaHCO}_{3}$, and $1.72 \mathrm{~g}(8 \mathrm{mmol})$ of $\mathrm{NaIO}_{4}$ with vigorous stirring. After $90 \mathrm{~min}$ at $25^{\circ}$, the reaction mixture was poured into $40 \mathrm{ml}$ of $15 \%$ ether-pentane and $40 \mathrm{ml}$ of saturated $\mathrm{NaHCO}_{3}$ solution. The organic layer was washed with $\mathrm{H}_{2} \mathrm{O}$ and $\mathrm{NaCl}$ solution. A few crystals of hydroquinone were added, solvent was removed, and the residue was distilled $(0.2 \mathrm{~mm}$, receiver at $-20^{\circ}$ ), giving $404 \mathrm{mg}$ ( $89 \%$ yield) of 1-phenyl-2-propen-1-one, ${ }^{34}$ with no detectable impurities by NMR: $\delta 5.84$ (dd, $J=2.2,10.7$ $\mathrm{Hz}, 1 \mathrm{H}), 6.39(\mathrm{dd}, J=2.2,17.3 \mathrm{~Hz}, 1 \mathrm{H}), 7.16(\mathrm{dd}, J=10.7$, $17.3 \mathrm{~Hz}, 1 \mathrm{H}), 7.4-7.6(\mathrm{~m}, 3 \mathrm{H}), 7.92(\mathrm{dd}, J=2,8 \mathrm{~Hz}, 2 \mathrm{H})$; ir $1672,1664,1610,1597 \mathrm{~cm}^{-1}$.

B. Run 3. The following serves as a typical procedure for the conversion of enol acetates to $\alpha$-phenylseleno ketones. To a stirred solution of $243 \mathrm{mg}(1.1 \mathrm{mmol})$ silver trifluoroacetate ${ }^{33 \mathrm{e}}$ in $5 \mathrm{ml}$ of benzene at $25^{\circ}$ under nitrogen was added a solution of $176 \mathrm{mg}$ ( 1 $\mathrm{mmol}$ ) of $(Z)$-1-acetoxy-1-phenylpropene in $0.5 \mathrm{ml}$ of benzene followed by $1.1 \mathrm{mmol}$ of $\mathrm{PhSeBr}$. After stirring the reaction mixture for 1 min, 2 drops of saturated $\mathrm{NaCl}$ solution was added along with $124 \mathrm{mg}(1 \mathrm{mmol})$ of $\mathrm{Na}_{2} \mathrm{CO}_{3} \cdot \mathrm{H}_{2} \mathrm{O}$ in $0.4 \mathrm{ml}$ of water. After filtering the reaction mixture through Celite and $\mathrm{Na}_{2} \mathrm{SO}_{4}$, solvent removal followed by preparative TLC gave $240 \mathrm{mg}(83 \%)$ of 1 - phenyl-2-phenylseleno-1-propanone (2).

C. From 1-Phenylpropyne. Silver trifluoroacetate $(112 \mathrm{mg}, 0.5$ $\mathrm{mmol}$ ) was stirred with $2 \mathrm{ml}$ of dry dichloromethane, and $97 \mathrm{mg}$ $(0.5 \mathrm{mmol})$ of $\mathrm{PhSeCl}$ was added. When the $\mathrm{PhSeCl}$ had dissolved ( $2 \mathrm{~min}$ ), the pale yellow suspension was added with stirring to 62 $\mathrm{mg}(0.53 \mathrm{mmol})$ of 1-phenyl-1-propyne in $2 \mathrm{ml}$ of dichloromethane. After $10 \mathrm{~min}$, this suspension was added to $0.75 \mathrm{mmol}$ of $\mathrm{KOH}$ and one drop of saturated aqueous $\mathrm{NaCl}$ solution in $5 \mathrm{ml}$ of ethanol. After stirring for $5 \mathrm{~min}, 20 \mathrm{ml}$ of $50 \%$ ether-pentane and $20 \mathrm{ml}$ of water were added, and the mixture was filtered through Celite. The organic layer was washed with $\mathrm{NaHCO}_{3}$ solution and dried. Solvent was removed, and the product was purified by preparative TLC, giving $95 \mathrm{mg}$ (66\%) of 1-phenyl-2-phenylseleno-1propanone (2)

trans-1-Phenyl-2-buten-1-one. A. Run 4. Following the selenide preparation outlined in run $1,2.96 \mathrm{~g}(0.02 \mathrm{mmol})$ of $n$-butyrophenone gave $5.00 \mathrm{~g}(82 \%)$ of 1-phenyl-2-phenylseleno-1-butanone after slow crystallization at $-24^{\circ}$ from $25 \mathrm{ml}$ of $50 \%$ ether-pentane: $\mathrm{mp} 50.5-52.5^{\circ}$; NMR $\delta 1.01(\mathrm{t}, J=6.9 \mathrm{~Hz}, 3 \mathrm{H}), 1.6-2.2$ $(\mathrm{m}, 2 \mathrm{H}), 4.30(t, J=7.2 \mathrm{~Hz}, 1 \mathrm{H}), 7.0-7.5(\mathrm{~m}, 8 \mathrm{H}), 7.77(\mathrm{~m}, 2$ H); ir $1678,1599,1581 \mathrm{~cm}^{-1}$.

Anal. Calcd for $\mathrm{C}_{16} \mathrm{H}_{16}$ OSe: C, 63.37; H, 5.32; Se, 26.04. Found: C, 63.45; H, 5.28; Se, 25.86.

Into a $250-\mathrm{ml}$ three-necked round-bottomed flask equipped with a dropping funnel, condenser, and thermometer was added a solution of $4.55 \mathrm{~g}(0.015 \mathrm{~mol}$ ) of selenide (prepared as above) in $50 \mathrm{ml}$ of dichloromethane containing $2.42 \mathrm{ml}(0.03 \mathrm{~mol})$ of pyridine. To the stirred solution was gradually added $0.04 \mathrm{~mol}$ of $\mathrm{H}_{2} \mathrm{O}_{2}(4.53 \mathrm{~g}$ of $30 \% \mathrm{H}_{2} \mathrm{O}_{2}$ in $4 \mathrm{ml}$ of water), with cooling by an ice-salt bath to keep the temperature between 30 and $35^{\circ}$ (CAUTION). ${ }^{35}$ The reaction mixture was stirred vigorously at $25^{\circ}$ for an additional 15 $\mathrm{min}$ after removing the bath and then was added to $25 \mathrm{ml}$ of dichloromethane and $30 \mathrm{ml}$ of $7 \% \mathrm{NaHCO}_{3}$ solution. The aqueous layer was washed with $25 \mathrm{ml}$ of dichloromethane, and the combined organic layers were washed with $30 \mathrm{ml}$ of $10 \% \mathrm{HCl}$ solution and $30 \mathrm{ml}$ of saturated $\mathrm{NaCl}$ and dried $\left(\mathrm{Na}_{2} \mathrm{SO}_{4}\right)$. After solvent removal, distillation gave $2.02 \mathrm{~g}(92 \%)$ of trans-enone: bp $84-85^{\circ}$ $(0.5 \mathrm{~mm})$ [lit. ${ }^{36}$ bp of cis, trans mixture $\left.120-122^{\circ}(7 \mathrm{~mm})\right] ;$ NMR $\delta 1.89(\mathrm{~d}, J=5.2 \mathrm{~Hz}, 3 \mathrm{H}), 6.72-7.15(\mathrm{~m}, 2 \mathrm{H}), 7.4(\mathrm{~m}, 3 \mathrm{H}), 7.84$ $(\mathrm{m}, 2 \mathrm{H})$.

B. Run 5. To a magnetically stirred solution of $1.2 \mathrm{mmol}$ of LDA in $5 \mathrm{ml}$ of freshly distilled THF under nitrogen at $-78^{\circ}$ was added a solution of $148 \mathrm{mg}(1 \mathrm{mmol})$ of $n$-butyrophenone in $0.5 \mathrm{ml}$ of THF. After stirring the reaction mixture for $10 \mathrm{~min}$, a solution of $374 \mathrm{mg}$ ( $1.8 \mathrm{mmol}$, weighed in a dry bag) of benzeneseleninyl chloride (26) in $1 \mathrm{ml}$ of THF was added, followed immediately by a solution of $72 \mathrm{mg}(1.2 \mathrm{mmol})$ of acetic acid in $0.5 \mathrm{ml}$ of THF. The reaction mixture was warmed to $25^{\circ}$ over a $15 \mathrm{~min}$ period. Normal work-up and purification by preparative TLC gave $117 \mathrm{mg}(80 \%$ yield) of trans-1-phenyl-2-buten-1-one.

trans-2-Hepten-4-one (Run 6). The selenide preparation in run 1 was followed using $0.105 \mathrm{~mol}$ of LDA in $50 \mathrm{ml}$ of THF, a solution of $11.42 \mathrm{~g}(0.1 \mathrm{~mol})$ of 4-heptanone in $10 \mathrm{ml}$ of THF, and a solution of $0.11 \mathrm{~mol}$ of $\mathrm{PhSeBr}$ in $30 \mathrm{ml}$ of THF. The reaction mixture was added to $100 \mathrm{ml}$ of $10 \% \mathrm{HCl}$ solution and $100 \mathrm{ml}$ of $50 \%$ ether-pentane. The aqueous layer was washed with $50 \mathrm{ml}$ of etherpentane, and the combined organic layers were washed with $50 \mathrm{ml}$ of $7 \% \mathrm{NaHCO}_{3}$ solution, $50 \mathrm{ml}$ of saturated $\mathrm{NaCl}$ solution, and dried $\left(\mathrm{Na}_{2} \mathrm{SO}_{4}\right)$. After solvent removal, remaining 4-heptanone $(\sim 5 \%)$ was removed under vacuum with a Dry Ice trap, leaving crude 3-phenylseleno-4-heptanone: NMR $\delta 0.7-1.1(\mathrm{~m}, 6 \mathrm{H})$, 1.3-2.0 (m, $4 \mathrm{H}), 2.1-2.8(\mathrm{~m}, 2 \mathrm{H}), 3.51(\mathrm{t}, J=7 \mathrm{~Hz}, 1 \mathrm{H}), 7.0-$ $7.7(\mathrm{~m}, 5 \mathrm{H})$.

The oxidation procedure outlined in run 4 was followed by slowly (CAUTION ${ }^{35}$ ), adding $0.3 \mathrm{~mol}$ of $\mathrm{H}_{2} \mathrm{O}_{2}\left(34.1 \mathrm{~g}\right.$ of $30 \% \mathrm{H}_{2} \mathrm{O}_{2}$ in $30 \mathrm{ml}$ of water) to a solution of the crude selenide in $150 \mathrm{ml}$ of dichloromethane containing $17 \mathrm{ml}(0.2 \mathrm{~mol})$ of pyridine, cooled by an ice-salt bath, to keep the temperature between 30 and $35^{\circ}$. The reaction was worked up by washing with a solution of $15.5 \mathrm{~g}(0.125$ mol) of $\mathrm{Na}_{2} \mathrm{CO}_{3} \cdot \mathrm{H}_{2} \mathrm{O}$ in $50 \mathrm{ml}$ of water (save), twice with $100 \mathrm{ml}$ of $10 \% \mathrm{HCl}$ solution, and $50 \mathrm{ml}$ of saturated $\mathrm{NaCl}$ solution and drying $\left(\mathrm{Na}_{2} \mathrm{SO}_{4}\right)$. Distillation gave $8.07 \mathrm{~g}(72 \%$ yield, $76 \%$ based on recovered 4-heptanone) of trans-enone: bp $53-54^{\circ}(15 \mathrm{~mm})$ [lit. ${ }^{36} \mathrm{bp}$ of cis,trans mixture $\left.78-80^{\circ}(50 \mathrm{~mm})\right]$; NMR $\delta 0.89(\mathrm{t}, J$ $=7.2 \mathrm{~Hz}, 3 \mathrm{H}), 1.58($ sextet, $J=7.2 \mathrm{~Hz}, 2 \mathrm{H}), 1.87(\mathrm{dd}, J=2$, $6.8 \mathrm{~Hz}, 3 \mathrm{H}), 2.44(\mathrm{t}, J=7.2 \mathrm{~Hz}, 2 \mathrm{H}), 6.04(\mathrm{dd}, J=2,15.8 \mathrm{~Hz}$, 
$1 \mathrm{H}), 6.76(\mathrm{dq}, J=15.8,6.8 \mathrm{~Hz}, 1 \mathrm{H})$

Recovery of Diphenyl Diselenide. The aqueous sodium carbonate wash from the oxidation procedure outlined in run 7 was neutralized with concentrated $\mathrm{HCl}$ and kept acidic by further additions of acid, while $48.2 \mathrm{~g}(0.306 \mathrm{~mol})$ of sodium thiosulfate was added gradually over a $30-\mathrm{min}$ period. After stirring the solution for $2 \mathrm{hr}$. an additional $7.9 \mathrm{~g}(0.05 \mathrm{~mol})$ of sodium thiosulfate was added, and the solution was stirred for $18 \mathrm{hr}$ as $\mathrm{Ph}_{2} \mathrm{Se}_{2}$ precipitated. The crude $\mathrm{Ph}_{2} \mathrm{Se}_{2}$ was isolated by filtration $(15.26 \mathrm{~g}, 89 \%)$ and was recrystallized from ethanol to give $12.0 \mathrm{~g}$ ( $70 \%$, two crops), $\mathrm{mp} 59-$ $60^{\circ}$.

1-Cyclobutenylphenyl Ketone (Run 9). Following the selenide preparation outlined in run $1,400 \mathrm{mg}(2.5 \mathrm{mmol})$ of cyclobutylphenyl ketone gave $679 \mathrm{mg}(87 \%)$ of 1 -phenylseleno-1-cyclobutylphenyl ketone, after preparative TLC: NMR $\delta 1.7-3.0(\mathrm{~m}, 6 \mathrm{H})$, $7.0-7.5(\mathrm{~m}, 8 \mathrm{H}), 7.87(\mathrm{~m}, 2 \mathrm{H})$; ir (neat) $1665,1595,1580,968$ $\mathrm{cm}^{-1}$.

To a stirred solution of $315 \mathrm{mg}(1 \mathrm{mmol})$ of selenide in $5 \mathrm{ml}$ of dichloromethane containing $0.2 \mathrm{ml}(2.4 \mathrm{mmol})$ of pyridine was added $8.8 \mathrm{mmol}$ of $\mathrm{H}_{2} \mathrm{O}_{2}$ ( $1 \mathrm{ml}$ of $30 \% \mathrm{H}_{2} \mathrm{O}_{2}$ in $1 \mathrm{ml}$ of water), and the reaction mixture was stirred at $25^{\circ}$ for $30 \mathrm{~min}$. Normal workup gave $131 \mathrm{mg}(83 \%)$ of enone, after preparative TLC: NMR $\delta$ $2.50(\mathrm{~m}, 2 \mathrm{H}), 2.82(\mathrm{~m}, 2 \mathrm{H}), 6.60(\mathrm{~m}, 1 \mathrm{H}), 7.40(\mathrm{~m}, 3 \mathrm{H}), 7.85$ $(\mathrm{m}, 2 \mathrm{H})$; ir (neat) $1643,1600,1585 \mathrm{~cm}^{-1}$; m/e (calcd for $\left.\mathrm{C}_{11} \mathrm{H}_{10} \mathrm{O}, 158.07312\right) 158.07310$

3-Phenyl-2-cyclobutenone (Run 10). Following the selenide preparation outlined in run 1, except with enolate formation and rapid quench at $-100^{\circ}, 146 \mathrm{mg}(1 \mathrm{mmol})$ of 3-phenylcyclobutanone ${ }^{37}$ gave, after preparative TLC, $230 \mathrm{mg}$ (65\% pure, ca. $50 \%$ yield) of a mixture containing predominantly one isomer: NMR $\delta$ 2.8 -3.8 $(\mathrm{m}, 4 \mathrm{H}), 4.42(\mathrm{~d}, J=7.3 \mathrm{~Hz}, 1 \mathrm{H}), 7.0-7.4(\mathrm{br} \mathrm{s}, 8 \mathrm{H}), 7.55(\mathrm{~m}, 2$ $\mathrm{H})$.

A solution of $151 \mathrm{mg}(0.5 \mathrm{mmol})$ of impure selenide prepared above in $4 \mathrm{ml}$ of dichloromethane was ozonized at $-78^{\circ}$. After the addition of $0.1 \mathrm{ml}(1.2 \mathrm{mmol})$ of pyridine, the reaction mixture was warmed to $25^{\circ}$ and was worked up as usual. Preparative TLC ( $50 \%$ ether-pentane) gave $30 \mathrm{mg}$ of enone $(83 \%$ pure, ca. $53 \%$ yield from pure selenide): $\operatorname{NMR}^{37} \delta 3.44(\mathrm{~s}, 2 \mathrm{H}), 6.32(\mathrm{~s}, 1 \mathrm{H})$, $7.5(\mathrm{~m}, 5 \mathrm{H})$; ir $1767,1609,1585,1566 \mathrm{~cm}^{-\mathrm{i}}$.

2-Benzylcyclopentanone. This compound was prepared by the procedure of Forward and Whiting: ${ }^{38}$ NMR $\delta 1.2-2.7(\mathrm{~m}, 8 \mathrm{H})$, $3.06(\mathrm{dd}, J=13.5,3.5 \mathrm{~Hz}, 1 \mathrm{H}), 7.0-7.4(\mathrm{~m}, 5 \mathrm{H})$. These authors incorrectly reported the resonance at $\delta 3.06$ as a two proton doublet.

5-Benzyl-2-cyclopenten-1-one (Run 11). Following the selenide preparation outlined in run 1 and the oxidation procedure in run 9 , $174 \mathrm{mg}$ (1 mmol) of 2-benzylcyclopentanone gave $113 \mathrm{mg}(66 \%)$ of enone, after preparative TLC (50\% ether-pentane): NMR $\delta$ 2.15-2.85 (m, $4 \mathrm{H}), 2.9-3.3(\mathrm{~m}, 1 \mathrm{H}), 6.11(\mathrm{dt} \mathrm{m}, J=5.5,2,<1$ $\mathrm{Hz}, 1 \mathrm{H}), 7.2$ (br s, $5 \mathrm{H}$ ), 7.54 (dt $\mathrm{m}, J=5.5,2.5,<1 \mathrm{~Hz}, 1 \mathrm{H}$ ); ir (neat) $1698,1638,1600,1588 \mathrm{~cm}^{-1} ; \mathrm{m} / \mathrm{e}$ (calcd for $\mathrm{C}_{12} \mathrm{H}_{12} \mathrm{O}$, $172.08878) 172.08873$.

1-Acetoxy-2-benzylcyclopentene. Using the method of House,

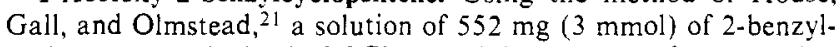
cyclopentanone in $3 \mathrm{ml}$ of $\mathrm{CCl}_{4}$ containing $0.75 \mathrm{ml}$ of acetic anhydride and $10 \mu \mathrm{l}$ of $60 \% \mathrm{HClO}_{4}$ was stirred at $25^{\circ}$, under nitrogen, for $1.5 \mathrm{hr}$ and worked up. Preparative TLC gave $484 \mathrm{mg}(78 \%$ yield) of enol acetate: NMR $\delta 1.7-2.3(\mathrm{~m}, 4 \mathrm{H}), 2.07(\mathrm{~s}, 3 \mathrm{H}), 2.5$ (m, $2 \mathrm{H}), 3.27$ (br s, $2 \mathrm{H}), 7.16(\mathrm{~m}, 5 \mathrm{H})$; ir $1755,1696(\mathrm{w}), 1210$ $\mathrm{cm}^{-1} ; m / e$ (calcd for $\left.\mathrm{C}_{14} \mathrm{H}_{16} \mathrm{O}_{2}, 216.11496\right) 216.11419$.

2-Benzylidinecyclopentanone and 2-Benzyl-2-cyclopenten-1-one (Run 12). Following the selenide preparation outlined in run 3,432 $\mathrm{mg}$ (2 mmol) of 1-acetoxy-2-benzylcyclopentene gave $603 \mathrm{mg}$ (96\%) of 2-benzyl-2-phenylselenocyclopentanone, after preparative TLC: $\mathrm{mp} 52-54^{\circ}$ (recrystallized from ether-pentane); NMR $\delta$ $1.6-2.5(\mathrm{~m}, 6 \mathrm{H}), 2.99$ and $3.25(\mathrm{AB} \mathrm{q}, J=13.8 \mathrm{~Hz}, 2 \mathrm{H}), 6.9-7.6$ $(\mathrm{m}, 10 \mathrm{H})$; ir $1727,1601(\mathrm{w}), 1580(\mathrm{w}) \mathrm{cm}^{-i}$.

Anal. Calcd for $\mathrm{C}_{18} \mathrm{H}_{18} \mathrm{OSe}$ Se, 23.98. Found: $\mathrm{Se}, 23.58$.

Oxidation of $329 \mathrm{mg}(1 \mathrm{mmol})$ of selenide using the procedure described for run 9 gave a mixture of the exo- and endocyclic enones. The mixture was separated by using preparative TLC $(50 \%$ ether-pentane) to give $72 \mathrm{mg}(42 \%)$ of 2 -benzylidenecyclopentanone $\left[\mathrm{mp} 69-71^{\circ}\right.$ (lit. $\left.{ }^{39 \mathrm{a}} \mathrm{mp} 70-71^{\circ}\right)$; NMR ${ }^{39 \mathrm{~b}} \delta 1.7-2.5(\mathrm{~m}, 4$ $\mathrm{H}), 2.90(\mathrm{td}, J=7,2.4 \mathrm{~Hz}, 2 \mathrm{H}), 7.2-7.6(\mathrm{~m}, 6 \mathrm{H},=\mathrm{CH}$ and $\mathrm{ArH})]$ and $92 \mathrm{mg}$ (53\%) of 2-benzyl-2-cyclopenten-1-one [NMR ${ }^{39 b} \delta 2.14-2.63(\mathrm{~m}, 4 \mathrm{H}), 3.40(\mathrm{~m}, 2 \mathrm{H}), 7.01(\mathrm{~m}, 1 \mathrm{H})$,
7.17 (br s, $5 \mathrm{H})]$.

6-Methyl-2-cyclohexen-1-one (Run 15). Following the selenide preparation outlined in run $1,0.022 \mathrm{~mol}$ of LDA, $0.022 \mathrm{~mol}$ of $\mathrm{PhSeBr}$, and $0.02 \mathrm{~mol}(2.24 \mathrm{~g})$ of 2 -methylcyclohexanone gave crude 6-methyl-2-phenylselenocyclohexanone. Remaining starting material $(5 \%)$ was removed by sublimation at $40-45^{\circ}$ (Dry Ice cold finger, $0.2 \mathrm{~mm}$ ). The selenide was a mixture of cis,trans-2methyl-6-phenylselenocyclohexanones in a 1:1 ratio which could be separated by preparative TLC: NMR cis-selenide $\delta 1.06(\mathrm{~d}, J=$ $5.8 \mathrm{~Hz}, 3 \mathrm{H}), 1.6-2.6(\mathrm{~m}, 7 \mathrm{H}), 4.01$ (dd, $\left.J=11,5 \mathrm{~Hz}, 1 \mathrm{H}, \mathrm{H}_{6}\right)$, $7.2-7.7(\mathrm{~m}, 5 \mathrm{H})$; trans-selenide, $\delta 1.01(\mathrm{~d}, J=5.6 \mathrm{~Hz}, 3 \mathrm{H})$, $1.6-2.5(\mathrm{~m}, 6 \mathrm{H}), 3.12$ (sextet, $J=6.4 \mathrm{~Hz}, 1 \mathrm{H}, \mathrm{H}_{2}$ ), 3.82 (br t, $J$ $\left.=4 \mathrm{~Hz}, 1 \mathrm{H}, \mathrm{H}_{6}\right), 7.2-7.7(\mathrm{~m}, 5 \mathrm{H})$.

A solution of the crude selenide in $20 \mathrm{ml}$ of dichloromethane was cooled to $-78^{\circ}$ and ozonized until green. Nitrogen was bubbled in until excess ozone had been removed and $2.8 \mathrm{ml}(20 \mathrm{mmol})$ of cold diisopropylamine were added. The cold solution was transferred by cannula to a refluxing $\mathrm{CCl}_{4}$ solution $(100 \mathrm{ml})$ containing $1.4 \mathrm{ml}$ (10 mmol) of diisopropylamine. The solution was cooled to $25^{\circ}$, was washed with $30 \mathrm{ml}$ of $10 \% \mathrm{HCl}$ solution, $30 \mathrm{ml}$ of $7 \%$ $\mathrm{NaHCO}_{3}$ solution, $30 \mathrm{ml}$ of saturated $\mathrm{NaCl}$ solution, and dried $\left(\mathrm{Na}_{2} \mathrm{SO}_{4}\right)$. After solvent removal, distillation gave $1.39 \mathrm{~g}(63 \%$ yield) of enone, bp $76-78^{\circ}(15 \mathrm{~mm})\left[\right.$ lit $\left.{ }^{40} \mathrm{bp} 74-75^{\circ}(24 \mathrm{~mm})\right]$. An additional $0.21 \mathrm{~g}$ was isolated by preparative TLC (20\% etherpentane) of the pot residue, total yield: $73 \%$; NMR $\delta 1.10(\mathrm{~d}, J=$ $6.8 \mathrm{~Hz}, 3 \mathrm{H}), 1.45-2.55(\mathrm{~m}, 5 \mathrm{H}), 5.91(\mathrm{dt}, J=10.2 \mathrm{~Hz}, 1 \mathrm{H})$, $6.88(\mathrm{dt} \mathrm{m}, J=10,4, \sim 2 \mathrm{~Hz}, 1 \mathrm{H}$ ).

Preparative TLC of the distillation pot residue also gave $0.595 \mathrm{~g}$ (11\%) of 2-phenylseleno-2-cyclohexen-1-one: mp $42-43^{\circ}$ (recrystallized from ether-pentane); NMR $\delta 1.22(\mathrm{~d}, J=6.7 \mathrm{~Hz}, 3 \mathrm{H})$, 1.6-2.7 (m, 5 H), 6.23 (t, $J=4 \mathrm{~Hz}, 1 \mathrm{H}), 7.2-7.7(\mathrm{~m}, 5 \mathrm{H})$; ir $1675,1597,1580 \mathrm{~cm}^{-1}$

Anal. Calcd for $\mathrm{C}_{13} \mathrm{H}_{14}$ OSe: C, 58.87; H, 5.32. Found: C, 58.75; $\mathrm{H}, 5.37$.

Ethylene Ketal of 6-Methyl-2-cyclohexen-1-one (19). A solution of $0.4 \mathrm{ig}(1.53 \mathrm{mmol})$ of 2-methyl-6-phenylselenocyclohexanone in $35 \mathrm{ml}$ of benzene containing $5 \mathrm{ml}$ of ethylene glycol and $58 \mathrm{mg} \mathrm{p}$ $\mathrm{TsOH} \cdot \mathrm{H}_{2} \mathrm{O}$ was refluxed for $2.5 \mathrm{hr}$ with water removal. Normal work-up (four water washes) followed by preparative TLC gave the ketal selenide: yield $0.389 \mathrm{~g}(81 \%)$; mixture of cis and trans isomers; NMR $\delta 1.06,1.14(\mathrm{~d}, J=6.6,6.4 \mathrm{~Hz}, 3 \mathrm{H}), 1.2-2.3(\mathrm{~m}$, $7 \mathrm{H}), 3.20,3.44$ (dd, $\left.J=13,4,4.5,6.0,4.5 \mathrm{~Hz}, 1 \mathrm{H}, \mathrm{H}_{6}\right), 3.7-4.4$ ( $\mathrm{m}, 4 \mathrm{H}), 7.0-7.7(\mathrm{~m}, 5 \mathrm{H})$.

A solution of $556 \mathrm{mg}(1.79 \mathrm{mmol})$ of the ethylene ketal of 2 methyl-6-phenylselenocyclohexanone and $0.32 \mathrm{ml}$ of pyridine in 15 $\mathrm{ml}$ of dichloromethane was stirred with $4 \mathrm{ml}$ of $15 \% \mathrm{H}_{2} \mathrm{O}_{2}$ for 1.5 hr. Normal work-up gave the selenoxide, which was refluxed for 5 min in $5 \mathrm{ml}$ of $\mathrm{CCl}_{4}$ containing $0.32 \mathrm{ml}$ of pyridine to cause elimination. Purification by preparative TLC gave $0.221 \mathrm{~g}(80 \%$ yield) of 19: NMR $\delta 0.89(\mathrm{~d}, J=6.0 \mathrm{~Hz}, 3 \mathrm{H}), 1.5-2.2(\mathrm{~m}, 5 \mathrm{H}), 3.6-4.0$ $(\mathrm{m}, 4 \mathrm{H}), 5.45(\mathrm{dt}, J=9.6,1.8 \mathrm{~Hz}, 1 \mathrm{H}), 5.74(\mathrm{dt}, J=9.6,3.6$ $\mathrm{Hz}, 1 \mathrm{H}$ ): m/e (calcd for $\left.\mathrm{C}_{9} \mathrm{H}_{14} \mathrm{O}_{2}, 154.09938\right) 154.09939$.

6-Phenyl-2-cyclohexen-1-one (Run 16). The selenide was prepared as in run 1 , using $174 \mathrm{mg}(1.0 \mathrm{mmol})$ of 2-phenylcyclohexanone, $1.1 \mathrm{mmol}$ of LDA, and $213 \mathrm{mg}(1.1 \mathrm{mmol})$ of $\mathrm{PhSeCl}$. The mixture of cis,trans isomers of 6-phenyl-2-phenylselenocyclohexanone was oxidized as in run 9 (stirred for $5 \mathrm{~min}$ with $\mathrm{H}_{2} \mathrm{O}_{2}$ ). The crude product was purified by preparative TLC, giving $103 \mathrm{mg}$ of enone $\left(60 \%\right.$ yield): $\mathrm{mp} 65-67^{\circ}$ (lit. $\left.{ }^{\text {le }} \mathrm{mp} 68-69^{\circ}\right)$; NMR $\delta 1.9-2.4$ $(\mathrm{m}, 4 \mathrm{H}), 3.43$ (br t, $J=7.2 \mathrm{~Hz}, 1 \mathrm{H}), 5.96(\mathrm{dt}, J=10.1,1.8 \mathrm{~Hz}$, $1 \mathrm{H}) .6 .81(\mathrm{dt}, J=10.1,3.5 \mathrm{~Hz}, 1 \mathrm{H}), 6.9-7.3(\mathrm{~m}, 5 \mathrm{H})$; ir 1675 , $1618,1603 \mathrm{~cm}^{-1}$.

Additional runs as above, except that method D (run 15) was used for the oxidation-elimination, gave $62 \%$ of enone with diisopropylamine as base and $58 \%$ yield when pyrolysis was carried out in the presence of diethylamine.

1-Acetoxy-2-phenylcyclohexene. Using the method of House, Gall, and Olmstead, 21 a solution of $2.12 \mathrm{~g}$ of 2-phenylcyclohexanone in $12 \mathrm{ml}$ of $\mathrm{CCl}_{4}$ containing $5 \mathrm{ml}$ of acetic anhydride and 2 drops of $60 \% \mathrm{HClO}_{4}(25 \mathrm{mg})$ was stirred at $25^{\circ}$ for $3 \mathrm{hr}$, and worked up. Distillation gave $2.11 \mathrm{~g}$ of enol acetate ${ }^{41}$ ( $80 \%$ yield); NMR and gas chromatographic analysis ( 300 -ft capillary column, Carbowax, $180^{\circ}$ ) showed the presence of $10 \%$ of the isomeric enol acetate (1-acetoxy-6-phenylcyclohexanone, relative retention time 1.1): NMR $\delta 1.78(\mathrm{~s}+\mathrm{m}, 7 \mathrm{H}), 2.0-2.4(\mathrm{~m}, 4 \mathrm{H}), 7.1(\mathrm{~m}, 5 \mathrm{H})$.

1-Acetoxy-6-phenylcyclohexene. The lithium enolate of 2-phen- 
ylcyclohexanone was quenched with acetic anhydride, and the product was analyzed by GLC as above, showing a $99 / 1$ ratio of 6-phenyl to 2-phenyl compounds: NMR $\delta 1.5-2.4(\mathrm{~m}, 6 \mathrm{H}), 1.73$ $(\mathrm{s}, 3 \mathrm{H}), 3.7(\mathrm{~m}, 1 \mathrm{H}), 5.50(\mathrm{td}, J=3.7,1.2 \mathrm{~Hz}, 1 \mathrm{H}), 7.1(\mathrm{~m}, 5$ $\mathrm{H})$.

2-Phenyl-2-cyclohexen-1-one (Run 18). A solution of $1.6 \mathrm{ml}$ of $1.55 \mathrm{M}$ methyllithium $(2.5 \mathrm{mmol})$ in $2 \mathrm{ml}$ of THF was cooled to $-20^{\circ}$ under nitrogen. To the stirred solution was added a solution of $0.216 \mathrm{~g}(1.0 \mathrm{mmol})$ of 1-acetoxy-2-phenylcyclohexene in THF. The mixture was warmed to $0^{\circ}$, stirred for $10 \mathrm{~min}$, and cooled to $-78^{\circ}$, and a solution of $2.75 \mathrm{mmol}$ of $\mathrm{PhSeBr}$ in $3 \mathrm{ml}$ of THF was added rapidly dropwise. The contents of the flask was added to 0.5 $N \mathrm{HCl}$ and $50 \%$ ether-pentane. Normal work-up and preparative TLC purification (chloroform-hexane) gave $0.302 \mathrm{~g}$ ( $87 \%$ yield) of 2-phenyl-2-phenylselenocyclohexanone. Crystallization from ether-pentane gave selenide with $\mathrm{mp} 116-117^{\circ}$ : NMR $\delta 1.5-2.1$ $(\mathrm{m}, 4 \mathrm{H}), 2.1-2.9(\mathrm{~m}, 4 \mathrm{H}), 6.9-7.4(\mathrm{~m}, 10 \mathrm{H})$; ir $\left(\mathrm{CHCl}_{3}\right) 1718$ $\mathrm{cm}^{-1}$.

Oxidation of $0.404 \mathrm{~g}(1.2 \mathrm{mmol})$ of the above selenide as in run 9 followed by preparative TLC (chloroform-hexane) gave $0.202 \mathrm{~g}$

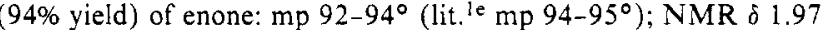
(quint, $2 \mathrm{H}), 2.4(\mathrm{~m}, 4 \mathrm{H}), 6.88(\mathrm{t}, J=5 \mathrm{~Hz}, 1 \mathrm{H}), 7.22$ (br s, 5 $\mathrm{H})$; ir $1686 \mathrm{~cm}^{-1}$

6-(p-Tolylidene)-2-cyclohexen-1-one (Run 19). To a solution of 6 mmol of LDA (from $0.92 \mathrm{ml}$ of $\mathrm{HN}-i-\mathrm{Pr}_{2}$ and $2.94 \mathrm{ml}$ of $2.05 \mathrm{M}$ $n$-BuLi) in $10 \mathrm{ml}$ of THF at $-78^{\circ}$ was added $1.2 \mathrm{ml}$ of hexamethylphosphoric triamide. A solution of 2-( $p$-tolylidene) cyclohexanone ${ }^{42}(1.0 \mathrm{~g}, 5 \mathrm{mmol})$ in $3 \mathrm{ml}$ of THF was added dropwise, followed after $10 \mathrm{~min}$ by a solution of $6 \mathrm{mmol}$ of $\mathrm{PhSeBr}$ (from $0.94 \mathrm{~g} \mathrm{Ph}_{2} \mathrm{Se}_{2}$ and $0.162 \mathrm{ml}$ of $\mathrm{Br}_{2}$ ) in $3 \mathrm{ml}$ of THF. The reaction mixture was worked up as usual. Crystallization from methanol $\left(-20^{\circ}\right)$ gave $1.10 \mathrm{~g}, \mathrm{mp} 70.5-72^{\circ}$. The mother liquor was purified by preparative TLC and recrystallized from methanol for a total yield of $1.20 \mathrm{~g}(68 \%)$ : NMR $\delta 1.6-3.1(\mathrm{~m}, 6 \mathrm{H}), 2.38(\mathrm{~s}, 3 \mathrm{H}), 4.01$ (br t, $J=5 \mathrm{~Hz}, 1 \mathrm{H}), 7.1-7.4(\mathrm{~m}, 8 \mathrm{H}), 7.58(\mathrm{~m}, 2 \mathrm{H})$; ir 1676, $1600(\mathrm{br}) \mathrm{cm}^{-1}$

Anal. Calcd for $\mathrm{C}_{20} \mathrm{H}_{20} \mathrm{OSe}$ : C, 67.60; H, 5.67. Found: C, 67.49; H, 5.56.

To a solution of $320 \mathrm{mg}(0.9 \mathrm{mmol})$ of the above selenide in 50 $\mathrm{ml}$ of warm methanol was added $15 \mathrm{ml}$ of water. The resulting suspension was cooled to $10^{\circ}$, and $430 \mathrm{mg}(2.0 \mathrm{mmol})$ of $\mathrm{NaIO}_{4}$ was added. The mixture was stirred at room temperature for $3 \mathrm{hr}$, then worked up by pouring into $40 \mathrm{ml}$ of $50 \%$ ether-pentane and $40 \mathrm{ml}$ of saturated $\mathrm{NaHCO}_{3}$ solution. The crude product was purified by preparative TLC (20\% ether-pentane) and crystallized from pentane to give $133 \mathrm{mg}(74 \%)$ of dienone: $\mathrm{mp} 63-65^{\circ}$; NMR $\delta 2.34(\mathrm{~s}$ $\left.+\mathrm{m}, 5 \mathrm{H}, \mathrm{CH}_{3}+\mathrm{H}_{4}\right), 2.97\left(\mathrm{dt}, J_{5,4}=6, J_{5,7}=1.9 \mathrm{~Hz}, \mathrm{H}_{5}\right), 6.08$ $\left(\mathrm{dt}, J_{2,3}=10, J_{2,4}=2.0 \mathrm{~Hz}, \mathrm{H}_{2}\right), 6.88\left(\mathrm{dt}, J_{3.2}=10, J_{3,4}=4.0\right.$ $\mathrm{Hz}, \mathrm{H}_{3}$ ), $7.13(\mathrm{AB} \mathrm{q}, J=7 \mathrm{~Hz}, 4 \mathrm{H}, \mathrm{ArH}), 7.41$ (br s, $\mathrm{H}_{7}$ ); ir $1672,1610 \mathrm{~cm}^{-1} ; \mathrm{m} / \mathrm{e}$ (calcd for $\left.\mathrm{C}_{14} \mathrm{H}_{14} \mathrm{O}, 198.10446\right) 198.10186$.

2-Cyclohepten-1-one (Run 22). Following the procedure outlined in run $15,20 \mathrm{mmol}(2.24 \mathrm{~g})$ of cycloheptanone gave, by distillation, $1.10 \mathrm{~g}(50 \%)$ of enone: bp $26-38^{\circ}(0.3 \mathrm{~mm})$ [lit. ${ }^{i c} 52-52.5^{\circ}$ $(2.4 \mathrm{~mm})$ ]; NMR $\delta 1.6-2.0(\mathrm{~m}, 4 \mathrm{H}), 2.2-2.6(\mathrm{~m}, 4 \mathrm{H}), 5.81(\mathrm{br} \mathrm{d}$, $J=11.8 \mathrm{~Hz}, 1 \mathrm{H}), 6.42(\mathrm{dt}, J=11.8,5.2 \mathrm{~Hz}, 1 \mathrm{H})$. Preparative TLC of the distillation pot residue (20\% ether-pentane) gave 0.96 g (18\%) of 2-phenylseleno-2-cyclohepten-1-one: mp 43-45\%; NMR $\delta$ 1.5-2.1 (m, $4 \mathrm{H}), 2.1-2.7(\mathrm{~m}, 4 \mathrm{H}), 6.24(\mathrm{t}, J=6 \mathrm{~Hz}, 1 \mathrm{H})$, 7.1-7.7 (m, $5 \mathrm{H})$; ir $1667,1594,1580 \mathrm{~cm}^{-1} ; \mathrm{m} / \mathrm{e}$ (calcd for $\left.\mathrm{C}_{13} \mathrm{H}_{14} \mathrm{OSe}, 266.02098\right) 266.02033$

Run 23. An identical run with the one above using diethylamine instead of diisopropylamine during the selenoxide pyrolysis gave $55 \%$ of enone and no 2-phenylseleno-2-cyclohepten-1-one.

Ethylene Ketal of 2-Phenylselenocycloheptanone. Following the selenide preparation outlined in run $1,280 \mathrm{mg}(2.5 \mathrm{mmol})$ of cycloheptanone gave $641 \mathrm{mg}$ ( $84 \%$ pure, ca. $81 \%$ yield) of 2-phenylselenocycloheptanone after preparative TLC: NMR $\delta 1.1-2.5(\mathrm{~m}$, $9 \mathrm{H}), 1.5-2.9(\mathrm{~m}, 2 \mathrm{H}), 3.70(\mathrm{dd}, J=11,5.5 \mathrm{~Hz}, 1 \mathrm{H}), 7.1-7.7$ $(\mathrm{m}, 5 \mathrm{H})$.

A solution of the selenide prepared above in $65 \mathrm{ml}$ of benzene containing $10 \mathrm{ml}$ of ethylene glycol and $120 \mathrm{mg}$ of $p-\mathrm{TsOH} \cdot \mathrm{H}_{2} \mathrm{O}$ was refluxed for $2.5 \mathrm{hr}$ with water removal. After work-up as described for the preparation of the ethylene ketal of 2-methyl-6phenylselenocyclohexanone, preparative TLC gave $570 \mathrm{mg}(90 \%$ yield from pure selenide): $\mathrm{mp} 40-42^{\circ}$; NMR $\delta 1.1-2.2(\mathrm{~m}, 10 \mathrm{H})$, $3.48(\mathrm{dd}, J=8.2,4 \mathrm{~Hz}, 1 \mathrm{H}), 3.7-4.2(\mathrm{~m}, 4 \mathrm{H}), 7.19(\mathrm{~m}, 3 \mathrm{H})$, $7.56(\mathrm{~m}, 2 \mathrm{H})$; ir $1580 \mathrm{~cm}^{-1}$.

Anal. Calcd for $\mathrm{C}_{15} \mathrm{H}_{20} \mathrm{O}_{2} \mathrm{Se}: \mathrm{Se}, 25.37$. Found: Se, 25.15 .

Ethylene Ketal of 2-Cyclohepten-1-one (20). Following the oxidation procedure outlines in run 9 (stirred for $2 \mathrm{hr}$ with $\mathrm{H}_{2} \mathrm{O}_{2}$ ), $157 \mathrm{mg}(0.5 \mathrm{mmol})$ of the ethylene ketal of 2-phenylselenocycloheptanone gave $67 \mathrm{mg}(87 \%)$ of $20^{1 \mathrm{c}}$ after preparative TLC: NMR ô $1.5-1.9(\mathrm{~m}, 6 \mathrm{H}), 2.2(\mathrm{~m}, 2 \mathrm{H}), 3.86(\mathrm{~s}, 4 \mathrm{H}), 5.59(\mathrm{~d}, J=12 \mathrm{~Hz}$, l $\mathrm{H}), 5.78(\mathrm{dt}, J=12,5.5 \mathrm{~Hz}, 1 \mathrm{H})$.

Spiro[2.6]non-5-en-4-one (Run 24). Following the selenide prepa-

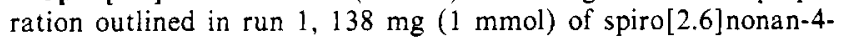
one ${ }^{43}$ gave $249 \mathrm{mg}$ ( $85 \%$ yield) of 5 -phenylselenospiro[2.6] nonan-4one after preparative TLC: $\mathrm{mp} 50-52^{\circ}$ (recrystallized from etherpentane); NMR $\delta 0.64(\mathrm{~m}, 2 \mathrm{H}), 1.24(\mathrm{~m}, 2 \mathrm{H}), 1.4-2.2(\mathrm{~m}, 8 \mathrm{H})$ 4.23 (dd, $J=6.6,4.2 \mathrm{~Hz}, 1 \mathrm{H}), 7.1-7.7(\mathrm{~m}, 5 \mathrm{H})$; ir 3080,3065 , $1673,1582,1480,1452,1440 \mathrm{~cm}^{-1}$.

Anal. Caled for $\mathrm{C}_{15} \mathrm{H}_{18}$ OSe: $\mathrm{C}, 61.43 ; \mathrm{H}, 6.19$. Found: $\mathrm{C}, 61.48$; $\mathrm{H}, 6.04$

Following the oxidation procedure outlined in run $15,293 \mathrm{mg} \mathrm{(1}$ $\mathrm{mmol}$ ) of selenide gave $116 \mathrm{mg}(85 \%)$ of enone after preparative TLC: NMR $\delta 0.65$ and $1.22\left(\mathrm{AA}^{\prime} \mathrm{BB}^{\prime}, 4 \mathrm{H}\right), 1.5-2.1(\mathrm{~m}, 4 \mathrm{H})$, $2.45(\mathrm{~m}, 2 \mathrm{H}), 5.87(\mathrm{dt}, J=12.2,1.7 \mathrm{~Hz}, 1 \mathrm{H}), 6.28(\mathrm{dt}, J=12.2$, $4.5 \mathrm{~Hz}, 1 \mathrm{H}$ ); ir (neat) $3095,1660(\mathrm{sh}), 1645,1453,1440 \mathrm{~cm}^{-1}$; $m / e$ (calcd for $\mathrm{C}_{9} \mathrm{H}_{12} \mathrm{O}, 136.08876$ ) 136.08891.

Methyl 1-Cyclohexenecarboxylate (Run 28). To a stirred solution of $6 \mathrm{mmol}$ of LDA in $20 \mathrm{ml}$ of THF under nitrogen at $-78^{\circ}$ was added dropwise a solution of $0.71 \mathrm{~g}(5 \mathrm{mmol})$ of methyl cyclohexanecarboxylate in $2 \mathrm{ml}$ of THF over $5 \mathrm{~min}$. After stirring for an additional $10 \mathrm{~min}$, a solution of $6 \mathrm{mmol}$ of $\mathrm{PhSeBr}$ in $2 \mathrm{ml}$ of THF was added rapidly. Upon warming the reaction to $0^{\circ}$ (ice water bath), water $(3 \mathrm{ml})$ and acetic acid $(0.6 \mathrm{ml}, 10 \mathrm{mmol})$ were added, followed by the slow addition of $2.8 \mathrm{~g}$ of $30 \% \mathrm{H}_{2} \mathrm{O}_{2}$, keeping the temperature below $25^{\circ}$. After stirring for $30 \mathrm{~min}$ at $25^{\circ}$, the reaction was worked up as usual. Distillation gave $0.675 \mathrm{~g}(96 \%)$ of methyl 1-cyclohexenecarboxylate: bp $75-76^{\circ}(15 \mathrm{~mm})$ [lit. ${ }^{44} \mathrm{bp}$ 47-50 $(2 \mathrm{~mm})]$; NMR $\delta 1.45-1.85(\mathrm{~m}, 4 \mathrm{H}), 2.0-2.4(\mathrm{~m}, 4 \mathrm{H})$, $3.67(\mathrm{~s}, 3 \mathrm{H}), 6.90(\mathrm{~m}, 1 \mathrm{H})$.

Methyl 1-cyclohexane-1-phenylselenocarboxylate can be isolated by work-up prior to oxidation: $m p 46-47^{\circ}$ (crystallized from pentane); NMR $\delta 1.1-1.9(\mathrm{~m}, 8 \mathrm{H}), 1.9-2.3(\mathrm{~m}, 2 \mathrm{H}), 3.60(\mathrm{~s}, 3$ $\mathrm{H}), 7.2-7.7(\mathrm{~m}, 5 \mathrm{H})$; ir $1726,1578(\mathrm{w}) \mathrm{cm}^{-1}$.

Anal. Caled for $\mathrm{C}_{14} \mathrm{H}_{18} \mathrm{O}_{2} \mathrm{Se}$ : Se, 26.56. Found: Se, 25.90.

6-Hydroxy-2-hexenoic Acid 6 -Lactone (Run 31). Following the selenide preparation outlined in run $1,0.572 \mathrm{~g}(5 \mathrm{mmol})$ of $\mathrm{\epsilon}$-caprolactone gave $0.935 \mathrm{~g}(70 \%)$ of 2-phenylseleno-6-hydroxyhexanoic acid $\epsilon$-lactone by slow crystallization from pentane at $-24^{\circ}$. mp 73-75'; NMR $\delta\left(\mathrm{CDCl}_{3}\right)$ 1.5-2.2 (m, $\left.6 \mathrm{H}\right), 4.28(\mathrm{~m}, 2 \mathrm{H})$, 4.55 (ddd, $J=13,5.5,3.5 \mathrm{~Hz}, 1 \mathrm{H}), 7.28(\mathrm{~m}, 3 \mathrm{H}), 7.55(\mathrm{~m}, 2 \mathrm{H})$, ir $\left(\mathrm{CHCl}_{3}\right) 1716(\mathrm{br}), 1581(\mathrm{w}) \mathrm{cm}^{-1}$

Anal. Calcd for $\mathrm{C}_{12} \mathrm{H}_{14} \mathrm{O}_{2} \mathrm{Se}: \mathrm{C}, 53.54: \mathrm{H}, 5.24$. Found: $\mathrm{C}$, $53.50 ; \mathrm{H}, 5.18$.

A solution of $135 \mathrm{mg}(0.5 \mathrm{mmol})$ of the above selenide in $2 \mathrm{ml}$ of dichloromethane was ozonized at $-78^{\circ}$ and then warmed to room temperature with stirring $(10 \mathrm{~min})$. Solvent was removed, and the residue was immediately sublimed at $50^{\circ}$ (Dry lce cold finger, 0.2 $\mathrm{mm}$ ) to give $60 \mathrm{mg}$ of material [ $80 \% \alpha, \beta$-unsaturated lactone (ca. $66 \%$ yield), $6 \% \mathrm{Ph}_{2} \mathrm{Se}_{2}, 14 \%$ unknown]: NMR $\delta 1.8-2.3(\mathrm{~m}, 2 \mathrm{H})$, 2.3-2.7(m, $2 \mathrm{H}), 4.17(\mathrm{~m}, 2 \mathrm{H}), 5.91(\mathrm{dt}, J=12.5,1.7 \mathrm{~Hz}, 1 \mathrm{H})$, $6.25(\mathrm{dt}, J=12.5,4.4 \mathrm{~Hz}, 1 \mathrm{H})$; ir $1709(\mathrm{br}), 1640(\mathrm{sh}) \mathrm{cm}^{-1} ; \mathrm{m} / \mathrm{e}$ (calcd for $\mathrm{C}_{6} \mathrm{H}_{8} \mathrm{O}_{2}, 112.05240$ ) 112.05231.

2-Carbethoxy-2-cyclohexen-1-one (Run 34). To a stirred suspension of $0.63 \mathrm{~g}(15 \mathrm{mmol})$ of $\mathrm{NaH}$ (57\% dispersion in mineral oil; washed free of oil with $3 \times 25 \mathrm{ml}$ of pentane) in $30 \mathrm{ml}$ of THF under nitrogen at $0^{\circ}$ was added dropwise a solution of $1.86 \mathrm{~g}(10$ $\mathrm{mmol}$ ) of 2-carbethoxycyclohexanone in $2 \mathrm{ml}$ of THF over a 15 min period. A solution of $2.11 \mathrm{~g}(11 \mathrm{mmol})$ of benzeneselenenyl chloride in $5 \mathrm{ml}$ of THF was added rapidly, and the reaction mixture was slowly added with stirring to $50 \mathrm{ml}$ of $50 \%$ ether-pentane, $25 \mathrm{ml}$ of saturated $\mathrm{NaHCO}_{3}$ solution, and some ice. The aqueous layer was washed with $50 \mathrm{ml}$ of $50 \%$ ether-pentane. The combined organic layers were washed with $25 \mathrm{ml}$ of saturated $\mathrm{NaCl}$ solution and dried $\left(\mathrm{Na}_{2} \mathrm{SO}_{4}\right)$. 2-Carbethoxy-2-phenylselenocyclohexanone had: NMR $\delta 1.18(\mathrm{t}, J=7 \mathrm{~Hz}, 3 \mathrm{H}), 1.3-2.6(\mathrm{~m}, 8 \mathrm{H}), 4.08(\mathrm{q}, J$ $=7 \mathrm{~Hz}, 2 \mathrm{H}), 7.24(\mathrm{~m}, 3 \mathrm{H}), 7.48(\mathrm{~m}, 2 \mathrm{H})$; ir $1712 \mathrm{~cm}^{-1}$

Into a $100-\mathrm{ml}$ three-necked round-bottomed flask equipped with a dropping funnel, condenser, and thermometer was added the crude selenide in $30 \mathrm{ml}$ of $\mathrm{CH}_{2} \mathrm{Cl}_{2}$. To the magnetically stirred so- 
lution was gradually added $25 \mathrm{mmol}$ of $\mathrm{H}_{2} \mathrm{O}_{2}\left(2.83 \mathrm{~g}\right.$ of $30 \% \mathrm{H}_{2} \mathrm{O}_{2}$ in $2.5 \mathrm{ml}$ of water) over a $10-\mathrm{min}$ period with occasional cooling in an ice bath to keep the temperature between 20 and $30^{\circ}$ (CAUTION: ${ }^{35}$ do not add more than $10 \%$ of the $\mathrm{H}_{2} \mathrm{O}_{2}$ solution until oxidation has begun). After stirring for an additional $10 \mathrm{~min}$ at $25^{\circ}$, the reaction mixture was poured into $25 \mathrm{ml}$ of $\mathrm{CH}_{2} \mathrm{Cl}_{2}$ and $10 \mathrm{ml}$ of $10 \% \mathrm{Na}_{2} \mathrm{CO}_{3}$ with stirring. The aqueous layer was washed with $25 \mathrm{ml}$ of $\mathrm{CH}_{2} \mathrm{Cl}_{2}$. The combined organic layers were washed with $25 \mathrm{ml}$ of saturated $\mathrm{NaCl}$ solution and dried $\left(\mathrm{Na}_{2} \mathrm{SO}_{4}\right)$. Solvent removal gave $1.88 \mathrm{~g}$ of 2-carbethoxy-2-cyclohexen-1-one. ${ }^{18}$ Distillation [Kugelrohr, $70^{\circ}(0.08 \mathrm{~mm})$ ] gave $1.63 \mathrm{~g}(89 \%)$ of a $92: 8 \mathrm{mix}-$ ture of keto:enol forms of the cyclohexenone (to minimize enolization the glassware used during the distillation was cleaned with $\mathrm{CrO}_{3} \cdot \mathrm{H}_{2} \mathrm{SO}_{4}$ and soaked in $\left.\mathrm{NH}_{4} \mathrm{OH}\right)$ : NMR $\delta 1.29(\mathrm{t}, J=7 \mathrm{~Hz}, 3$ H), $2.06(\mathrm{~m}, 2 \mathrm{H}), 2.46(\mathrm{~m}, 4 \mathrm{H}), 4.19(\mathrm{q}, J=7 \mathrm{~Hz}, 2 \mathrm{H}), 7.49(\mathrm{t}$, $J=4 \mathrm{~Hz}, 1 \mathrm{H})$; ir $1736,1712,1695,1621 \mathrm{~cm}^{-1} ; \mathrm{m} / \mathrm{e}$ (calcd for $\left.\mathrm{C}_{9} \mathrm{H}_{12} \mathrm{O}_{4}, 184.07349\right) 184.07319$.

2-Carbethoxy-2-cyclopenten-1-one (Run 35). The commercially available 2:1 mixture of 2-carbethoxy- and 2-carbomethoxycyclopentanones $(0.76 \mathrm{~g}, 5 \mathrm{mmol})$ was converted to selenide using the procedure for run 34: NMR $\delta 1.21(\mathrm{t}, J=7 \mathrm{~Hz}, 3 \mathrm{H}), 1.6-2.6(\mathrm{~m}$, $6 \mathrm{H}), 4.08(\mathrm{q}, J=7 \mathrm{~Hz}, 2 \mathrm{H}), 7.0-7.4(\mathrm{~m}, 3 \mathrm{H}), 7.4-7.6(\mathrm{~m}, 2 \mathrm{H})$.

The crude 2-carbethoxy-2-phenylselenocyclopentanone in $15 \mathrm{ml}$ of $\mathrm{CH}_{2} \mathrm{Cl}_{2}$ was oxidized as in run 34 , using $2.15 \mathrm{ml}$ of $15 \% \mathrm{H}_{2} \mathrm{O}_{2}$ solution $(9.5 \mathrm{mmol}){ }^{35}$ It is essential to avoid excess $\mathrm{H}_{2} \mathrm{O}_{2}$. After completion of the oxidation, the organic layer was washed twice with $10 \mathrm{ml}$ of $\mathrm{H}_{2} \mathrm{O}$, and each aqueous portion was back extracted with two 2-ml portions of $\mathrm{CH}_{2} \mathrm{Cl}_{2}$. The combined organic layers were dried $\left(\mathrm{Na}_{2} \mathrm{SO}_{4}\right)$ and evaporated. To the residue was added 10 $\mathrm{ml}$ of ether to precipitate the benzeneseleninic acid, which was filtered (removal of $\mathrm{PhSeO}_{2} \mathrm{H}$ by $\mathrm{NaHCO}_{3}$ extraction appears to cause a small amount of decomposition of the base-sensitive enone). The filtrate was evaporated and distilled [Kugelrohr, 60$\left.65^{\circ}(0.05 \mathrm{~mm})\right]$, to yield $0.605 \mathrm{~g}(81 \%)$ of enone ${ }^{2 \mathrm{~b}}(2: 1$ mixture of ethyl and methyl esters) which was $\sim 90 \%$ pure by NMR: $\delta 1.32$ (t, $J=7 \mathrm{~Hz}, 3 \mathrm{H}), 2.4(\mathrm{~m}, 2 \mathrm{H}), 2.7(\mathrm{~m}, 2 \mathrm{H}), 4.18(\mathrm{q}, J=7 \mathrm{~Hz}, 2$ H), $8.29(\mathrm{t}, J=2.6 \mathrm{~Hz}, 1 \mathrm{H})$; ir $1761,1729,1626,1550 \mathrm{~cm}^{-1}$

2-Acetyl-2-cyclohexen-1-one. 2-Acetylcyclohexanone ${ }^{46 a}(1.40 \mathrm{~g}$, $10 \mathrm{mmol}$ ) was converted to selenide using the procedure of run 34 . Pure 2-acetyl-2-phenylselenocyclohexanone can be isolated by preparative TLC of a sample of crude selenide: $\mathrm{mp} 72-73^{\circ}$ (crystallized from ether-pentane); NMR $\delta 1.3-2.3(\mathrm{~m}, 7 \mathrm{H}), 2.30(\mathrm{~s}, 3$ H), 2.5-2.8 (m, $1 \mathrm{H}), 7.28(\mathrm{~m}, 5 \mathrm{H})$; ir $1693,1579(\mathrm{w}) \mathrm{cm}^{-1}$.

Anal. Calcd for $\mathrm{C}_{14} \mathrm{H}_{16} \mathrm{O}_{2} \mathrm{Se}: \mathrm{C}, 56.96 ; \mathrm{H}, 5.46$. Found: $\mathrm{C}$, $57.12 ; \mathrm{h}, 5.48$

Run 36. The crude selenide prepared above was dissolved in 30 $\mathrm{ml}$ of dichloromethane and ozonized at $-78^{\circ}$. To the reaction mixture was added $2.0 \mathrm{ml}(24 \mathrm{mmol})$ of pyridine, and it was warmed to $25^{\circ}$ while stirring. After work-up as described for run 15 , sublimation at $35-40^{\circ}$ (Dry Ice cold finger, $0.2 \mathrm{~mm}$ ) gave $1.157 \mathrm{~g}$ of enone ( $84 \%$ yield < $1 \%$ enolized): NMR $\delta 1.9-2.2(\mathrm{~m}, 2 \mathrm{H}), 2.35$ $(\mathrm{s}, 3 \mathrm{H}), 2.3-2.7(\mathrm{~m}, 4 \mathrm{H}), 7.56(\mathrm{t}, J=4.3 \mathrm{~Hz}, 1 \mathrm{H})$; ir 1694,1602 $\mathrm{cm}^{-1} ; \mathrm{m} / \mathrm{e}$ (calcd for $\mathrm{C}_{8} \mathrm{H}_{10} \mathrm{O}_{2}, 138.06808$ ) 138.06819 .

Run 37. Following the oxidation procedure outlined in run 34 (using $10 \mathrm{mmol}$ of $\mathrm{H}_{2} \mathrm{O}_{2}$ ), $1.5 \mathrm{~g}$ ( $5 \mathrm{mmol}$ ) of crude selenide prepared as above gave $0.68 \mathrm{~g}$ of enone (ca. $91 \%$ pure, $<1 \%$ enolized). Distillation using a Kugelrohr $\left[40^{\circ}(0.07 \mathrm{~mm})\right]$ gave $582 \mathrm{mg}(84 \%$ yield) of a 85:15 mixture of keto:enol forms of 2-acetyl-2-cyclohexen-1-one.

Run 38. To a magnetically stirred solution of $1.5 \mathrm{~g}(5 \mathrm{mmol})$ of selenide in $30 \mathrm{ml}$ of $\mathrm{CH}_{2} \mathrm{Cl}_{2}$ was added in small portions $2.03 \mathrm{~g} \mathrm{(10}$ $\mathrm{mmol}$ ) of $m$-chloroperoxybenzoic acid (tech, $85 \%$ ) in small portions, keeping the temperature between 20 and $30^{\circ}$. Work-up as for run 34 followed by Kugelrohr distillation gave $586 \mathrm{mg}$ ( $85 \%$ yield) of 60:40 mixture of keto and enol forms of enone. The crude material was less than $2 \%$ enolized and is sufficiently pure for most purposes.

1-Phenyl-2-phenylthio-1-butanone. The lithium enolate of $1.48 \mathrm{~g}$ $(10 \mathrm{mmol})$ of $n$-butyrophenone was prepared at $-78^{\circ}$ as in run 1 , warmed to $25^{\circ}$, and added to $2.62 \mathrm{~g}(12 \mathrm{mmol})$ of diphenyl disulfide. ${ }^{10 \mathrm{~b}}$ After stirring for $20 \mathrm{~min}$ under nitrogen at $25^{\circ}$, the reaction mixture was worked up as usual with the substitution of a $2 \mathrm{~N}$ $\mathrm{NaOH}$ wash for $\mathrm{NaHCO}_{3}$. Preparative TLC followed by crystallization from pentane gave $1.17 \mathrm{~g}(46 \%)$ of sulfide: $\mathrm{mp} 40-42^{\circ}$; NMR $\delta 1.02(\mathrm{t}, J=7.7 \mathrm{~Hz}, 3 \mathrm{H}), 1.5-2.2(\mathrm{~m}, 2 \mathrm{H}), 4.27(\mathrm{t}, J=$ $7.4 \mathrm{~Hz}, 1 \mathrm{H}), 7.1-7.6(\mathrm{~m}, 8 \mathrm{H}), 7.88(\mathrm{~m}, 2 \mathrm{H})$; ir $1682,1600,1583$ $\mathrm{cm}^{-1} ; m / e$ (calcd for $\left.\mathrm{C}_{16} \mathrm{H}_{16} \mathrm{OS}, 256.09219\right) 256.09399$.

1-Phenyl-2-phenylsulfino-1-butanone. A mixture of $0.768 \mathrm{~g} \mathrm{(3}$ $\mathrm{mmol})$ of 1-phenyl-2-phenylthio-1-butanone and $1.28 \mathrm{~g}(6 \mathrm{mmol})$ of $\mathrm{NaIO}_{4}$ in $10 \mathrm{ml}$ of $80 \%$ aqueous methanol was stirred at $25^{\circ}$ under nitrogen for $24 \mathrm{hr}$. After filtration and solvent removal, the crude reaction mixture was added to $20 \mathrm{ml}$ of chloroform and was washed with $5 \mathrm{ml}$ of $7 \% \mathrm{NaHCO}_{3}$ solution and $10 \mathrm{ml}$ of saturated $\mathrm{NaCl}$ solution and dried $\left(\mathrm{MgSO}_{4}\right)$. Solvent removal, followed by preparative TLC, eluting first with $10 \%$ ether-pentane and then $5 \%$ methanol-ether gave $0.695 \mathrm{~g}(85 \%)$ of an equal mixture of diastereomers separable by crystallization from ether-pentane, $\mathrm{mp}$ 107.5-108.5 [NMR $\delta\left(\mathrm{CDCl}_{3}\right) 0.93(\mathrm{t}, J=7.3 \mathrm{~Hz}, 3 \mathrm{H}), 1.92$ (quintet, $J=7.2 \mathrm{~Hz}, 2 \mathrm{H}), 4.64(\mathrm{t}, J=7.1 \mathrm{~Hz}, 1 \mathrm{H}), 7.2-7.7(\mathrm{~m}$, $8 \mathrm{H}), 7.91(\mathrm{~m}, 2 \mathrm{H})$; ir $\left.\left(\mathrm{CHCl}_{3}\right) 1677,1598,1580,1048 \mathrm{~cm}^{-1}\right]$ and $\mathrm{mp} 67-68^{\circ}\left[\mathrm{NMR} \delta\left(\mathrm{CDCl}_{3}\right) 1.03(\mathrm{t}, J=7.8 \mathrm{~Hz}, 3 \mathrm{H}), 2.33\right.$ $(\mathrm{m}, 2 \mathrm{H}), 4.56(\mathrm{dd}, J=7.8,6 \mathrm{~Hz}, 1 \mathrm{H}), 7.1-7.9(\mathrm{~m}, 10 \mathrm{H})$; ir $\left.\left(\mathrm{CHCl}_{3}\right) 1670,1598,1580,1042 \mathrm{~cm}^{-1}\right]$.

1-Phenyl-2-phenylsulfino-2-buten-1-one (Run 41). Following the selenice preparation outlined in run $37,544 \mathrm{mg}(2 \mathrm{mmol})$ of 1 phenyl-2-phenylsulfino-1-butanone (mixture of diastereomers) gave $668 \mathrm{mg}(78 \%)$ of a viscous mixture of the diastereomers of 1 phenyl-2-phenylseleno-2-phenylsulfino-1-butanone after preparative TLC (50\% ether-pentane). Two crystallizations from etherpentane gave one diastereomer pure, which decomposed above $100^{\circ}$ : NMR $\delta\left(\mathrm{CDCl}_{3}\right) 0.78(\mathrm{t}, J=7 \mathrm{~Hz}, 3 \mathrm{H}), 1.5-1.9(\mathrm{~m}, 1 \mathrm{H})$, 2.55-2.95 (m, $1 \mathrm{H}), 7.0-8.2(\mathrm{~m}, 15 \mathrm{H})$; ir $\left(\mathrm{CDCl}_{3}\right) 1655,1598$, $1580,1228,1075,1040 \mathrm{~cm}^{-1}$

Anal. Calcd for $\mathrm{C}_{22} \mathrm{H}_{20} \mathrm{O}_{2} \mathrm{SSe}$ : C, 61.82; $\mathrm{H}, 4.72$. Found: $\mathrm{C}$, 61.79; H, 4.74 .

Following the oxidation procedure outlined in run 9 (stirring with $1.5 \mathrm{mmol}$ of $\mathrm{H}_{2} \mathrm{O}_{2}$ for $\left.20 \mathrm{~min}\right), 214 \mathrm{mg}(0.5 \mathrm{mmol})$ of sulfinyl selenide (mixture of diastereomers) gave $96 \mathrm{mg}$ ( $71 \%$ yield, $>93 \%$ one isomer) of sulfinyl enone after preparative TLC $(50 \%$ etherpentane). The material was crystallized twice from ether-pentane: mp 72-74०; NMR $\delta\left(\mathrm{CDCl}_{3}\right) 1.77(\mathrm{~d} J=7.2 \mathrm{~Hz}, 3 \mathrm{H}), 6.94$ (q, $J$ $=7.2 \mathrm{~Hz}, 1 \mathrm{H}), 7.2-7.7(\mathrm{~m}, 10 \mathrm{H})$; ir $\left(\mathrm{CHCl}_{3}\right) 1655(\mathrm{br}), 1598$, $1582,1225(\mathrm{br}), 1078,1042 \mathrm{~cm}^{-}$

Anal. Calcd for $\mathrm{C}_{16} \mathrm{H}_{14} \mathrm{O}_{2} \mathrm{~S}$ : C, 71.09; H, 5.22. Found: C, 71.19; $\mathrm{H}, 5.16$

Additional Spectral Data. Spectral properties of selenides and $\alpha, \beta$-unsaturated carbonyl compounds not discussed in detail above are given below.

Run 20. 3-Phenylselenobicyclo[3.2.1]octan-2-one (major isomer,

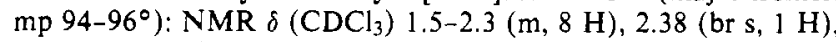
$2.92($ br s, $1 \mathrm{H}), 4.13$ (dd, $J=8.5,11.6 \mathrm{~Hz}, 1 \mathrm{H}), 7.24(\mathrm{~m}, 3 \mathrm{H})$, $7.52(\mathrm{~m}, 2 \mathrm{H})$; ir $\left(\mathrm{CHCl}_{3}\right) 1709,1581 \mathrm{~cm}^{-1}$

Anal. Calcd for $\mathrm{C}_{14} \mathrm{H}_{16} \mathrm{OSe}$ : Se. 28.28. Found: Se. 28.10.

Bicyclo[3.2.1]oct-3-en-2-one:46b NMR $\delta$ 1.2-2.4 (m, $6 \mathrm{H}), 2.7-$ $3.1(\mathrm{~m}, 2 \mathrm{H}), 5.67(\mathrm{dd}, J=9.7,1.5 \mathrm{~Hz}, 1 \mathrm{H}), 7.13$ (ddd, $J=9.7$, $7.0,1.5 \mathrm{~Hz}, 1 \mathrm{H}$ ); ir $1705,1675 \mathrm{~cm}^{-1} ; \mathrm{m} / e$ (calcd for $\mathrm{C}_{8} \mathrm{H}_{10} \mathrm{O}$, 122.07314) 122.07300.

Run 25. 7-Phenylseleno-2-cyclohepten-1-one: NMR $\delta$ 1.5-2.6 $(\mathrm{m}, 6 \mathrm{H}), 3.99$ (dd, $J=8,5 \mathrm{~Hz}, 1 \mathrm{H}), 5.95(\mathrm{dt}, J=12.5, \sim 1.5 \mathrm{~Hz}$, $1 \mathrm{H}), 6.26(\mathrm{dt}, J=12.5,4.8 \mathrm{~Hz}, 1 \mathrm{H}), 7.0-7.7(\mathrm{~m}, 5 \mathrm{H})$; ir 1659 , $1580 \mathrm{~cm}^{-1}$. 2,6-Cycloheptadien-1-one: NMR ic $\delta 2.47(\mathrm{~m}, 4 \mathrm{H})$, $5.98(\mathrm{brd} J=12 \mathrm{~Hz}, 1 \mathrm{H}), 6.62(\mathrm{dm}, J=12 \mathrm{~Hz}, 1 \mathrm{H})$; ir 1651 , $1616 \mathrm{~cm}^{-1}$

Run 26. trans-2-Cyclododecen-1-one: NMR $\delta 1.1-1.9$ (m, 14 H), 2.1-2.6 (m, $4 \mathrm{H}), 6.28(\mathrm{~d}, J=16.0 \mathrm{~Hz}, 1 \mathrm{H}), 6.73(\mathrm{dt}, J=$ $16.0,6.9 \mathrm{~Hz}, 1 \mathrm{H}) ; \mathrm{ir}^{46 \mathrm{c}} 1692,1661,1626 \mathrm{~cm}^{-1}$

Run 27. Ethyl 2-Phenyl-2-phenylseleno-2-butanoate: NMR $\delta$ $1.00(\mathrm{t}, J=7 \mathrm{~Hz}, 3 \mathrm{H}), 1.16(\mathrm{t}, J=7 \mathrm{~Hz}, 3 \mathrm{H}), 2.08(\mathrm{~m}, 2 \mathrm{H})$, $4.18(\mathrm{q}, J=7 \mathrm{~Hz}, 2 \mathrm{H}), 7.25(\mathrm{~m}, 10 \mathrm{H})$. (E)- and (Z)-Ethyl 2-Phenyl-2-butenoates ${ }^{46 d}$ (54:46 mixture): NMR $\delta 1.28,1.22$ (t, $J=7.1$ $\mathrm{Hz}, 3 \mathrm{H}), 2.02,1.72(\mathrm{~d}, J=7.2 \mathrm{~Hz}, 3 \mathrm{H}), 4.22,4.14(\mathrm{q}, J=7.1$ $\mathrm{Hz}, 2 \mathrm{H}), 6.16,7.06(\mathrm{q}, J=7.2 \mathrm{~Hz}, 1 \mathrm{H}), 7.0-7.4(\mathrm{~m}, 5 \mathrm{H})$; ir $1717 \mathrm{~cm}^{-1}$.

Run 29. Ethyl Bicyclo[2.2.2]octa-2,5-diene-2-carboxylate: NMR $\delta 1.30(\mathrm{t}, J=7.1 \mathrm{~Hz}, 3 \mathrm{H}), 1.33(\mathrm{~m}, 4 \mathrm{H}), 3.79(\mathrm{~m}, 1 \mathrm{H}), 4.19(\mathrm{q}$ $+\mathrm{m}, 3 \mathrm{H}$ ), 6.33, 6.45 (two td, $J=7,1.7 \mathrm{~Hz}, 2 \mathrm{H}$ ), 7.27 (dd, $J=$ $7.0,2.0 \mathrm{~Hz}, 1 \mathrm{H})$; ir $1597,1629,1701 \mathrm{~cm}^{-1}$.

Run 32. 2-Carbethoxy-2-phenylselenocyclooctanone: NMR $\delta$ $1.20(\mathrm{t}, J=6.8 \mathrm{~Hz}, 3 \mathrm{H}), 1.2-2.8(\mathrm{~m}, 12 \mathrm{H}), 4.10(\mathrm{q}, J=6.8 \mathrm{~Hz}$, $2 \mathrm{H})$, 7.2-7.7 (m, $5 \mathrm{H})$. 2-Carbethoxy-2-cycloocten-1-one: NMR $\delta$ $1.25(\mathrm{t}, J=6.8 \mathrm{~Hz}, 3 \mathrm{H}), 1.5-2.0(\mathrm{~m}, 6 \mathrm{H}), 2.1-2.6(\mathrm{~m}, 4 \mathrm{H}), 4.12$ $(\mathrm{q}, J=6.8 \mathrm{~Hz}, 2 \mathrm{H}), 7.04(\mathrm{t}, J=5.2 \mathrm{~Hz}, 1 \mathrm{H})$; ir 1727,1701 , 
$1642 \mathrm{~cm}^{-1} ;$ m/e (calcd for $\mathrm{C}_{11} \mathrm{H}_{16} \mathrm{O}_{3}, 196.10989$ ) 196.11024

Run 33. 2-Carbethoxy-2-phenylselenocycloheptanone: NMR $\delta$ $1.23(\mathrm{t}, J=7 \mathrm{~Hz}, 3 \mathrm{H}), 1.4-2.2(\mathrm{~m}, 8 \mathrm{H}), 2.52(\mathrm{~m}, 2 \mathrm{H}), 4.11(\mathrm{q}$, $J=7 \mathrm{~Hz}, 2 \mathrm{H}), 7.1-7.6(\mathrm{~m}, 5 \mathrm{H})$; ir 1724 (sh), 1708, $1580(\mathrm{w})$, $1224 \mathrm{~cm}^{-1}$. 2-Carbethoxy-2-cyclohepten-1-one:46e NMR $\delta 1.26(\mathrm{t}$, $J=7.2 \mathrm{~Hz}, 3 \mathrm{H}), 1.6-2.0(\mathrm{~m}, 4 \mathrm{H}), 2.3-2.7(\mathrm{~m}, 4 \mathrm{H}), 4.13(\mathrm{q}, J=$ $7.2 \mathrm{~Hz}, 2 \mathrm{H}), 7.16(\mathrm{t}, J=5.6 \mathrm{~Hz}, 1 \mathrm{H})$; ir $1725,1700,1638 \mathrm{~cm}^{-1}$; $m / e$ (calcd for $\left.\mathrm{C}_{10} \mathrm{H}_{14} \mathrm{O}_{3}, 182.09424\right) 182.09430$

Run 39. 3-Methyl-1-phenyl-2-phenylseleno-1,3-butanedione: $\mathrm{mp}$ $119-121^{\circ}$; NMR $\delta\left(\mathrm{CDCl}_{3}\right) 1.76(\mathrm{~s}, 3 \mathrm{H}), 2.32(\mathrm{~s}, 3 \mathrm{H}), 7.15-7.65$ $(\mathrm{m}, 8 \mathrm{H}), 7.88(\mathrm{~m}, 2 \mathrm{H})$; ir $1705,1672,1598,1581 \mathrm{~cm}^{-1}$. 2-Methylene-1-phenyl-1,3-butanedione:46f NMR $\delta 2.31(\mathrm{~s}, 3 \mathrm{H}), 5.86(\mathrm{~s}, 1$ H), $6.46(\mathrm{~s}, 1 \mathrm{H}), 7.3-7.7(\mathrm{~m}, 3 \mathrm{H}), 7.77(\mathrm{~m}, 2 \mathrm{H})$; ir 1725,1670 (br), $1597 \mathrm{~cm}^{-1}$

Run 40. 2-Butyl-1-phenyl-2-phenylseleno-1,3-butanedione: NMR $\delta 0.77(\mathrm{t}, J=7 \mathrm{~Hz}, 3 \mathrm{H}), 1.0-2.2(\mathrm{~m}, 6 \mathrm{H}), 2.29(\mathrm{~s}, 3 \mathrm{H})$, $7.1-7.5(\mathrm{~m}, 8 \mathrm{H}), 7.83(\mathrm{dd}, J=8,2 \mathrm{~Hz}, 2 \mathrm{H})$; ir $1698,1669 \mathrm{~cm}^{-1}$ 2-(1-Butylidene)-1-phenyl-1,3-butanedione: NMR $\delta 0.82$ (t, $J=7$ $\mathrm{Hz}, 3 \mathrm{H}), 1.43$ (sextet, $J=7 \mathrm{~Hz}, 2 \mathrm{H}), 1.99(\mathrm{q}, J=7 \mathrm{~Hz}, 2 \mathrm{H})$, $2.18(\mathrm{~s}, 3 \mathrm{H}), 6.86(\mathrm{t}, J=7.6 \mathrm{~Hz}, 1 \mathrm{H}), 7.4(\mathrm{~m}, 3 \mathrm{H}), 7.76(\mathrm{dd}, J$ $=8,2 \mathrm{~Hz}, 2 \mathrm{H}$ ); ir $1692,1669,1616,1603 \mathrm{~cm}^{-1} ; \mathrm{m} / \mathrm{e}$ (calcd for $\left.\mathrm{C}_{14} \mathrm{H}_{16} \mathrm{O}_{2}, 216.11496\right) 216.11514$.

3-Methyl-1-phenyl-2-phenylselenó-1-butanone (3). To a stirred suspension of $238 \mathrm{mg}(1.25 \mathrm{mmol})$ of cuprous iodide in $10 \mathrm{ml}$ of freshly distilled ether at $-40^{\circ}$ under nitrogen was added $1.52 \mathrm{ml}$ $(2.5 \mathrm{mmol})$ of $1.64 \mathrm{M}$ ethereal methyllithium. After stirring the solution for $2 \mathrm{~min}$, a solution of $146 \mathrm{mg}(1.0 \mathrm{mmol})$ of 1 -phenyl-2buten-1-one in $1 \mathrm{ml}$ of ether was added, followed by a solution of $\mathrm{PhSeBr}$ and $\mathrm{Ph}_{2} \mathrm{Se}_{2}$ [from $390 \mathrm{mg}(1.25 \mathrm{mmol})$ of $\mathrm{Ph}_{2} \mathrm{Se}_{2}$ and 45 $\mu \mathrm{l}(0.85 \mathrm{mmol})$ of $\mathrm{Br}_{2}$ in $2 \mathrm{ml}$ of THF]. The reaction mixture was added to $20 \mathrm{ml}$ of $50 \%$ ether-pentane and $10 \mathrm{ml}$ of saturated $\mathrm{NH}_{4} \mathrm{Cl}$ solution. Normal work-up followed by preparative TLC gave $264 \mathrm{mg}(83 \%)$ of $3: \mathrm{mp} 43-44^{\circ}$ (recrystallized from etherpentane); NMR o $0.96(\mathrm{~d}, J=6.8 \mathrm{~Hz}, 3 \mathrm{H}) .1 .26(\mathrm{~d}, J=6.8 \mathrm{~Hz}$, $3 \mathrm{H}), 2.1-2.5(\mathrm{~m}, 1 \mathrm{H}), 4.12(\mathrm{~d}, J=10 \mathrm{~Hz}, 1 \mathrm{H}) .7 .1-7.5(\mathrm{~m}, 8$ $\mathrm{H}), 7.77(\mathrm{~m}, 2 \mathrm{H})$; ir $1678,1596,1582 \mathrm{~cm}^{-1}$.

Anal. Caled for $\mathrm{C}_{17} \mathrm{H}_{18}$ OSe: C, 64.35; H, 5.72; Se, 24.89 Found: C, 64.31; H. 5.69; Se, 24,76.

3-Methyl-1-phenyl-2-buten-1-one (4). Oxidation of $159 \mathrm{mg}(0.5$ mmol) of 3 as in run 9 (stirring for 30 min with $\mathrm{H}_{2} \mathrm{O}_{2}$ ) followed by purification (preparative TLC) gave $70 \mathrm{mg}(87.5 \%$ yield) of 4 : $\mathrm{NMR}^{47} \delta 1.98(\mathrm{~d}, J=1.3 \mathrm{~Hz}, 3 \mathrm{H}), 2.17(\mathrm{~d}, J=1.3 \mathrm{~Hz}, 3 \mathrm{H})$ $6.62(\mathrm{~m}, 1 \mathrm{H}), 7.36(\mathrm{~m}, 3 \mathrm{H}), 7.79(\mathrm{~m}, 2 \mathrm{H})$; ir $1665,1616 \mathrm{~cm}^{-1}$.

2-Phenylselenocyclooctanone $(8 \mathrm{a})$. Following the selenide preparation outlined in run 1 using $10.5 \mathrm{mmol}$ of LDA and $11 \mathrm{mmol}$ of $\mathrm{PhSeBr}, 1.26 \mathrm{~g}(10 \mathrm{mmol})$ of cyclooctanone gave $1.92 \mathrm{~g}(70 \%$ yield, $>95 \%$ yield based on recovered cyclooctanone from sublimation of crude selenide) of $\mathbf{8 a}$ after purification by dry column chromatography on silica gel (10\% ether-pentane). The selenide was crystallized twice from pentane at $-24^{\circ}$ : mp 25.5-270; NMR $\delta$ $0.9-2.3(\mathrm{~m}, 11 \mathrm{H}), 2.70(\mathrm{td}, J=11,4.5 \mathrm{~Hz}, 1 \mathrm{H}), 3.58(\mathrm{dd}, J \simeq 7$, $6 \mathrm{~Hz}, 1 \mathrm{H}), 6.9-7.5(\mathrm{~m}, 5 \mathrm{H})$; ir $1691,1581 \mathrm{~cm}^{-1}$. This material was used in the mechanistic and yield experiments involving 13a.

Anal. Calcd for $\mathrm{C}_{14} \mathrm{H}_{18}$ OSe: $\mathrm{C}, 59.79 ; \mathrm{H}, 6.45$. Found: $\mathrm{C}, 59.78$; H. 6.51.

2-( $m$-Trifluoromethylphenylseleno)cyclooctanone $(8 \mathrm{~b})$. Following the selenide preparation outlined above, using $m$-trifluoromethylbenzeneselenenyl chloride instead of $\mathrm{PhSeBr}$, gave $2.27 \mathrm{~g}(65 \%$ yield) of $\mathbf{8 b}$. The selenide was crystallized twice from pentane at $-24^{\circ}$ : mp 36-38 ; NMR $\delta 0.9-2.4(\mathrm{~m}, 11 \mathrm{H}), 2.75$ (td, $J=11$, $4.5 \mathrm{~Hz}, 1 \mathrm{H}), 3.69(\mathrm{dd}, J \simeq 7.5,6.5 \mathrm{~Hz}, 1 \mathrm{H}), 7.1-7.9(\mathrm{~m}, 4 \mathrm{H})$; ir $1692,1600(\mathrm{w}), 1580 \mathrm{~cm}^{-1}$. This material was used in the mechanistic and yield experiments involving $13 \mathrm{~b}$.

Anal. Caled for $\mathrm{C}_{15} \mathrm{H}_{1}>\mathrm{F}_{3}$ OSe: C, 51.58; $\mathrm{H}, 4.91$. Found: $\mathrm{C}$, $51.52 ; \mathrm{H}, 4.94$

Comparative Elimination Products of $13 \mathrm{a}$ and $13 \mathrm{~b}$ (Table II). The following procedure for method $B$ serves as a typical model for the isolation and characterization of the compounds listed in Table II. To a stirred solution of $281 \mathrm{mg}(1 \mathrm{mmol})$ of $8 \mathbf{a}$ in $2 \mathrm{ml}$ of dichloromethane containing $0.2 \mathrm{ml}(2.4 \mathrm{mmol})$ of pyridine was added 3 mmol of $\mathrm{H}_{2} \mathrm{O}_{2}$ (341 $\mathrm{mg}$ of $30 \% \mathrm{H}_{2} \mathrm{O}_{2}$ in $0.3 \mathrm{ml}$ of water), and the reaction mixture was stirred at $25^{\circ}$ for $25 \mathrm{~min}$. The reaction mixture was added to $10 \mathrm{ml}$ of dichloromethane, was washed with 310 $\mathrm{mg}(2.5 \mathrm{mmol})$ of $\mathrm{Na}_{2} \mathrm{CO}_{3} \cdot \mathrm{H}_{2} \mathrm{O}$ in $1 \mathrm{ml}$ of water (save), $2 \mathrm{ml}$ of $10 \% \mathrm{HCl}$ solution, $2 \mathrm{ml}$ of saturated $\mathrm{NaCl}$, and dried $\left(\mathrm{Na}_{2} \mathrm{SO}_{4}\right)$. After solvent removal, sublimation at $50-60^{\circ}$ (Dry Ice cold finger,
$0.3 \mathrm{~mm}$ ) of the crude product gave $40 \mathrm{mg}$ of a mixture of 2 -cycloocten-1-one $(9)^{1 \mathrm{C}}$ and 1,2-cyclooctanedione (11) ${ }^{48}$ These were separated, and relative yields were determined by GLC ( $20 \% \mathrm{Car}$ bowax on Chrom $W, 150^{\circ}$ ) and NMR integration. 9: NMR $\delta$ $1.4-2.0(\mathrm{~m}, 6 \mathrm{H}), 2.3-2.7(\mathrm{~m}, 4 \mathrm{H}), 5.86($ br d, $J=12 \mathrm{~Hz}, 1 \mathrm{H})$, $6.31(\mathrm{dt}, J=12,6.7 \mathrm{~Hz}, 1 \mathrm{H})$; ir $1668 \mathrm{~cm}^{-1}$. 11: NMR $\delta 1.5-2.0$ $(8 \mathrm{H}, \mathrm{m}), 2.4-2.7(\mathrm{~m}, 4 \mathrm{H})$; ir $1709 \mathrm{~cm}^{-1}$. Quinoxaline derivative:

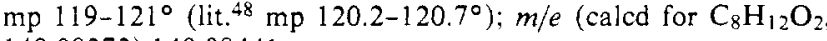
140.08373) 140.08441

The yield of 2-phenylseleno-2-cycloocten-1-one (10a) (and recovered $8 \mathbf{a}$ for method $\mathrm{C}$ ) was obtained by preparative TLC of the pot residue (20\% ether-pentane): NMR $\delta 1.4-2.0(\mathrm{~m}, 6 \mathrm{H}), 2.1$ $2.5(\mathrm{~m}, 4 \mathrm{H}), 6.27(\mathrm{t}, J=5.8 \mathrm{~Hz}, 1 \mathrm{H}), 7.2-7.7(\mathrm{~m}, 5 \mathrm{H})$; ir 1688 , $1658,1590(w), 1579 \mathrm{~cm}^{-1} ; m / e$ (calcd for $\mathrm{C}_{14} \mathrm{H}_{16} \mathrm{OSe}$, 280.03663) 280.03646 .

The aqueous $\mathrm{Na}_{2} \mathrm{CO}_{3}$ layer was acidified, washed with $25 \mathrm{ml}$ of ethyl acetate, and dried $\left(\mathrm{Na}_{2} \mathrm{SO}_{4}\right)$ to give $118 \mathrm{mg}$ of a $60: 40 \mathrm{mix}-$ ture of 1,8-octanedioic acid (12) and $\mathrm{PhSeO}_{2} \mathrm{H}$ by NMR analysis. Pure 12 was obtained by reducing the $\mathrm{PhSeO}_{2} \mathrm{H}$ to $\mathrm{Ph}_{2} \mathrm{Se}_{2}$

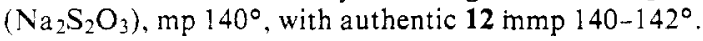

For the other entries in Table II, the oxidation procedures of run $1\left(\mathrm{NaIO}_{4}-\mathrm{NaHCO}_{3}\right)$, run 10 (method $\mathrm{C}$, no pyridine added), and run 15 (method D) were done on $1-\mathrm{mmol}$ samples of $\mathbf{8 a}$ and $\mathbf{8 b}$ as listed. The isolation and characterization techniques described above were used. With $\mathbf{8 b}, 2$-( $m$-trifluoromethylphenylseleno)-2cycloocten-1-one (10b) was obtained: NMR $\delta 1.4-2.0(\mathrm{~m}, 6 \mathrm{H})$, $2.2-2.6(\mathrm{~m}, 4 \mathrm{H}), 6.40(\mathrm{t}, J=5.7 \mathrm{~Hz}, 1 \mathrm{H}), 7.2-7.9(\mathrm{~m}, 4 \mathrm{H})$; ir $1688,1663,1591(w), 1580(w) \mathrm{cm}^{-1}$

Crossover Experiments (Table III). The oxidation procedures of run 10 (method $C$, no pyridine added) and run 15 (method D) were followed on mixtures of $\mathbf{8 b}$ and 1-phenyl-2-phenylseleno-1butanone as indicated in Table III. The relative yields of products $9,10 \mathrm{a}$, and $10 \mathrm{~b}$ were determined using the isolation and characterization techniques described in the Experimental Section for Table II

Redox Studies. A. Selenoxide (18) plus Selenide (2) (Equation 8). A solution of $76 \mathrm{mg}(0.25 \mathrm{mmol})$ of 1-phenyl-2-phenylseleno-1butanone in $1 \mathrm{ml}$ of dichloromethane was ozonized at $-78^{\circ}$, and $72 \mathrm{mg}(0.25 \mathrm{mmol})$ of 2 was added. The reaction mixture was warmed to $25^{\circ}$ and worked up as usual. The relative yields of products as indicated in eq 8 were determined by NMR comparison with known compounds. The addition of $0.5 \mathrm{mmol}$ of pyridine or diisopropylamine before warm-up gave only 1-phenyl-2-buten-1one and recovered 2.

B. Selenoxide (18) plus Selenol. The procedure above (A) was repeated with the substitution of $39 \mathrm{mg}(0.25 \mathrm{mmol})$ of benzeneselenol for 2 . The NMR of crude product indicated $>90 \%$ recovered 1-phenyl-2-phenylseleno-1-butanone and $<10 \% 1$-phenyl-2-buten1-one.

C. Selenoxide plus $\mathrm{H}_{2} \mathrm{SO}_{4}$ (Equation 7). A solution of $152 \mathrm{mg}$ $(0.5 \mathrm{mmol})$ of 1-phenyl-2-phenylseleno-1-butanone in $4 \mathrm{ml}$ of methanol was ozonized at $-40^{\circ}$, and $0.11 \mathrm{ml}$ of concentrated $\mathrm{H}_{2} \mathrm{SO}_{4}$ was added to give $0.5 \mathrm{M}$ methanolic $\mathrm{H}_{2} \mathrm{SO}_{4}$. The reaction mixture was warmed to $-5^{\circ}$ with stirring for $4 \mathrm{hr}$ and then left at $0^{\circ}$ for an additional $64 \mathrm{hr}$. Normal work-up and preparative TLC gave $106 \mathrm{mg} \mathrm{(68 \% )} \mathrm{of} \mathrm{recovered} \mathrm{selenide} \mathrm{and} 28 \mathrm{mg}$ ( $80 \%$ pure, ca. $22 \%$ yield) of 2,2-dimethoxy-1-phenyl-1-butanone: NMR $\delta 0.74(\mathrm{t}$, $J=7.7 \mathrm{~Hz}, 3 \mathrm{H}), 1.93(\mathrm{q}, J=7.7 \mathrm{~Hz}, 2 \mathrm{H}), 3.28(\mathrm{~s}, 6 \mathrm{H}), 7.4(\mathrm{~m}$, $3 \mathrm{H}), 8.16(\mathrm{~m}, 2 \mathrm{H})$; ir $1697,1598,1579 \mathrm{~cm}^{-1}$. Quinoxaline derivative of 1-phenyl-1,2-butanedione gave suitable physical and spectral properties. 49

Acknowledgment. We thank the donors of the Petroleum Research Fund, administered by the American Chemical Society, the National Science Foundation, the Du Pont Co. (Du Pont Young Faculty Grant), and the Wisconsin Alumni Research Foundation for support of this work.

\section{References and Notes}

(1) (a) E. A. Braude and E. A. Evans, J. Chem. Soc., 607 (1954); (b) R. Joly, J. Warnant, G. Namine, and D. Bertin, Bull. Soc. Chim. Fr., 366 (1958) (c) E. W. Garbisch, Jr., J. Org. Chiem., 30, 2109 (1965); (d) P. L. Stotter and K. L. Hill, ibid., 38, 2576 (1973); (e) B. Miller and H. S. Wong, Tetrahedron, 28, 2369 (1972); (f) M. E. McEntee and A. R. Pinder, J. Chem. Soc., $4419(1957)$; C. W. T. Hussey and A. R. Pinder, ibid., 3525 (1961); 1517 (1962); (g) J. E. Brenner, J. Org. Chem., 26, 22 (1961). 
(2) (a) R. A. Jerusl, Sel. Org. Transform., 1, 301 (1970); (b) J. N. Marx, J. H. Cox, and L. R. Norman, J. Org. Chem., 37, 4489 (1972); (c) D. Walker and J. D. Hiebert, Chem. Rev., 67, $153(1967)$; (d) A. F. Thomas and M. Ozainne, J. Chem. Soc. Chem. Commun., 746 (1973); (e) R. J. Theissen, J. Org. Chem., 36, 752 (1971); (f) T. Cohen, C. K. Shaw, and J. A Jenkins, ibid., 38, 3737 (1973)

(3) D. N. Jones, D. Mundy, and R. D. Whitehouse, J. Chem. Soc. Chem Commun., 86 (1970).

(4) (a) H. J. Reich, I. L. Reich, and J. M. Renga, J. Am. Chem. Soc., 95, 5813 (1973); (b) H. J. Reich, J. M. Renga, and I. L. Reich, J. Org. Chem., 39, 2133 (1974); (c) H. J. Reich, ibld. 39, 428 (1974); (d) H. J. Reich and S. K. Shah, J. Am. Chem. Soc., 97, $3250(1975) ;(\theta)$ H. J. Reich, J. Org. Chem., in press; (f) H. J. Reich and J. M. Renga, J. Chem. Soc. Chem. Commun., 135 (1974)

(5) (a) K. B. Sharpless, M. W. Young, and R. F. Lauer, Tetrahedron Lett. 1979 (1973); (b) K. B. Sharpless and R. F. Lauer, J. Am. Chem. Soc. 95, 2697 (1973); (c) K. B. Sharpless and R. F. Lauer, and A. Y. Teranishi, ibid., 95, 6137 (1973); (d) K. B. Sharpless and R. F. Lauer, J. Org. Chem., 39, 429 (1974); (e) K. B. Sharpless and M. W. Young, ibid., 40, $947(1975)$

(6) (a) D. L. J. Clive, J. Chem. Soc., Chem. Commun., 695 (1973); (b) D. L. J. Clive, bid., 100 (1974).

(7) (a) P. A. Grieco and M. Miyashita, J. Org. Chem., 39, 120 (1974); (b) J. L. Herrman, M. H. Berger, and R. H. Schlessinger, J. Am. Chem. Soc. 95, 7923 (1973); (c) P. A. Grieco and J. J. Reap, Tetrahedron Lett. 1097 (1974).

(8) D. N. Brattesani and C. H. Heathcock, Tetrahedron Lett., 2279 (1974)

(9) (a) D. Seebach and N. Peleties, Angew. Chem, 81, 465 (1969); Chem. Ber., 105, 511 (1972); (b) W. Dumont, P. Bayet, and A. Krief, Angew. Chem., Int. Ed. Engl., 13, 1804 (1974); (c) D. Seebach and A. K. Beck ibid., 13, 806 (1974)

(10) (a) B. M. Trost, W. P. Conway, P. E. Strege, and T. J. Dietsche, J. Am Chem. Soc. 96, 7165 (1974); (b) B. M. Trost and T. N. Salzmann, ibid., 95, 6840 (1973); (c) B. M. Trost and T. N. Salzmann, J. Org. Chem., 40, 148 (1975).

(11) R. H. Mitchell, J. Chem. Soc., Chem. Commun., 990 (1974)

(12) For comprehensive accounts of organoselenium chemistry, see (a) $T$ W. Campbell, H. G. Walker, and G. M. Coppinger, Chem. Rev, 50, 279 (1950); (b) H. Rheinboldt in "Houben Weyl. Methoden der Organischen Chemie, Schwefel-, Selen-, Tellurverbindungen", Vol. IX, 1955; (c) D. L. Klayman and W. H. H. Gunther, Ed., "Organic Selenium Compounds: Their Chemistry and Biology". Wiley, New York, N.Y., 1973.

(13) Reference $12 b, p 985$

(14) It is possible that reduction proceeds by attack of PhSeM on bromine, giving enolate and $\mathrm{PhSeBr}$. Under aprotic conditions, the enolate is then selenenylated but, under protic conditions, the enolate is protonated. A further complication is that $\alpha$-phenylseleno ketones are deselenenylated by $\mathrm{PhSeM}$ (see eq 2).

(15) (a) H. Rheinboldt and M. Perrier, Bull. Soc. Chim. Fr, 759 (1950): 484 (1953); (b) H. Rheinboldt and E. Giesbrecht, J. Am. Chem. Soc., 72, 866 (1950).

(16) (a) L. R. M. Pitombo, Chem. Ber., 92, 745 (1959); (b) N. N. Yarovenka, V. N. Shemania, and G. B. Gazieva, Zh. Obshch. Khim. 29, 942 (1959).

(17) $\alpha$-Alkylthio ketones are also cleaved by mercaptide ion [M. Oki, W. Fu nakoshi, and A. Nakamura, Bull. Chem. Soc. Jpn., 44, 828, 832 (1971)].

(18) (a) S. Brenner and M. Bovete, Tetrahedron Lett., 1377 (1974); (b) D. S. Watt, ibid., 707 (1974)

(19) (a) C. A. Brown, J. Org. Chem., 39, 1324 (1974); (b) C. A. Brown, J. Chem. Soc., Chem. Commun., 680 (1974).

(20) T. J. Brocksom, N. Petragnani, and R. Rodrigues, J. Org. Chem., 39, $2114(1974)$

(21) H. O. House, M. Gall, and H. D. Olmstead, J. Org. Chem., 36, 2361 (1971).

(22) (a) M. Cinquini, S. Colonna, and R. Giovini, Chem. Ind. (London), 1737
(1969); (b) G. Ayrey, D. Barnard, and D. T. Woodbridge, J. Chem. Soc., 2089 (1962); (c) E. S. Gould and J. D. McCullough, J. Am. Chem. Soc., $73,3196(1951)$

(23) (a) E. S. Gould and J. D. McCullough, J. Am. Chem. Soc., 73, 1109 (1951); (b) D. DeFilippo and F. Monicchioli, Tetrahedron, 25, 5733 (1969).

(24) We thank Professor B. M. Trost for a sample of spiro[4.3]octan-1-one. See B. M. Trost and M. J. Bogdanowicz, J. Am. Chem. Soc., 95, 5321 (1973).

(25) Hydrogen peroxide is known to cleave $\alpha$-diketones to dicarboxylic acids: J. E. Leffler, J. Org. Chem., 16, 1785 (1951); E. Kyburz, B. Riniker, H. R. Schenk, H. Heusser, and O. Jeger, Helv. Chim. Acta, 36, 1891 (1953).

(26) K. B. Sharpless and M. W. Young ${ }^{5 e}$ have also observed that electronwithdrawing substituents increase the facility of selenoxide elimination.

(27) We have, however, observed that intramolecular additions of selenenic acids to give $\beta$-hydroxyselenides can occur, and also that selenenamides can add to Michael acceptors to give $\beta$-aminoselenides $(H . J$. Reich, J. E. Trend, and J. M. Renga, unpublished results).

(28) J. L. Kice and J. P. Cleveland, J. Am. Chem. Soc., 95, 104, 109 (1973),

(29) Garbisch ${ }^{10}$ has effectively used ketals as a protecting group in the preparation of enones by dehydrobromination

(30) E. Vedejs, J. Am. Chem. Soc., 96, 5944 (1974).

(31) (a) M. Kocor and M. Tuszy-Maczka, Bull. Acad. Pol. Sci, Ser. Sci. Chim., 8, 405 (1961); (b) J. N. Marx and L. R. Norman, Tetrahedron Lett., 2867 (1973).

(32) E. S. Gould, Anal. Chem. 23, 1502 (1951)

(33) (a) D. G. Foster, "Organic Syntheses" Collect Vol 3, 1955, p 771; (b) F. Krafft and R. E. Lyons, Ber., 27, 1761 (1894); (c) D. G. Foster, Recl. Trav. Chim. Pays-Bas, 53, 408 (1934); (d) $O$. Behaghel and $H$. Seibert, Ber., 65, 812 (1932); (e) D. E. Janssen and C. V. Wilson, "Organic Syntheses", Collect. Vol. 4, 1963, p 547.

(34) I. G. Tishcenko, G. Z. Stasevich, and O. N. Bubel, Zh. Org. Khim., 1, 2444 (1971).

(35) It is advisable to add approximately $10 \%$ of peroxide solution at $25^{\circ}$ and then cool the reaction mixture with an ice bath when the reaction begins.

(36) M. Langlais, A. Buzas, G. Soussan, and P. Freon, C. R. Acad. Sci., 261, $2920(1965)$

(37) S. L. Manatt, M. Vogel, D. Knutson, and J. D. Roberts, J. Am. Chem Soc., 86, 2645 (1964)

(38) G. C. Forward and D. A. Whiting, J. Chem. Soc. C. 1868 (1969).

(39) (a) H. O. House and R. L. Wasson. J. Am. Chem. Soc. 78, 4394 (1956) (b) M. Elliott, N. F. Janes, and M. C. Payne, J. Chem. Soc. C, 2548 (1971).

(40) G. Stork and W. N. White, J. Am. Chem. Soc., 78, 4604 (1956).

(41) A. N. Kost and I. P. Sugrobova, Vestn. Mosk. Univ., Khim., 18, 75 (1963); Chem. Abstr., 59, 7460d (1963).

(42) J. Colonge and J. Sibeud, Bull. Soc. Chim. Fr., 786 (1952)

(43) P. Leriverend and J. M. Conia, Bull. Soc. Chim. Fr., 121 (1966).

(44) R. Damico, J. Org. Chem., 33, 1550 (1968)

(45) A. P. Krapcho, J. Diamanti, C. Cayan, and R. Bingham, Org. Synth., 47, $20(1967)$

(46) (a) G. Stork, A. Brizzolara, H. Landesman, J. Szmuszkovicz, and R. Terrell, J. Am. Chem. Soc., 85, 207 (1963); (b) J. Ficini and A. Maujean Bull. Soc. Chim. Fr., 4395 (1972); (c) H. Nozaki, T. Mori, and R. Noyori, Tetrahedron, 22, 1207 (1966); (d) M. J. D. van Dam, Recl. Trav. Chim. Pays-Bas, 83, 31 (1964); (e) C. F. Heubner, L. Dorfman, M. M. Robison, E. Donoghue, W. G. Pierson, and D. Strachan, J. Org. Chem., 28, 3134 (1963); (f) W. S. Trahanovsky and P. W. Mullen, J. Am. Chem Soc. 94 5086 (1972)

(47) R. F. J. Langendries and F. C. de Schryver, Tetrahedron Lett., 4781 (1972)

(48) A. T. Blomquist and L. H. Liu, J. Am. Chem. Soc., 75, 2153 (1953).

(49) Y. Pascal. Ann. Chim. (Paris), 3, 67 (1968). 